\title{
Role of a Dual Glucose-Dependent Insulinotropic Peptide (GIP)/Glucagon-like Peptide-1 Receptor Agonist (Twincretin) in Glycemic Control: From Pathophysiology to Treatment
}

\author{
Maria Chiara Pelle ${ }^{1}{ }^{(}$, Michele Provenzano ${ }^{2}\left(\mathbb{D}\right.$, Isabella Zaffina ${ }^{1}$, Roberta Pujia ${ }^{1}$, Federica Giofrè ${ }^{1}$, \\ Stefania Lucà ${ }^{1}$, Michele Andreucci ${ }^{2}$, Angela Sciacqua ${ }^{1}$ and Franco Arturi ${ }^{1, *}$ \\ 1 Department of Medical and Surgical Sciences, University “Magna Graecia” of Catanzaro, \\ 88100 Catanzaro, Italy; mcpelle@unicz.it (M.C.P.); zaffina86@gmail.com (I.Z.); robertapuj@gmail.com (R.P.); \\ federica.giofre@gmail.com (F.G.); lu.stef@tiscali.it (S.L.); sciacqua@unicz.it (A.S.) \\ 2 Department of Health Sciences, University "Magna Graecia" of Catanzaro, 88100 Catanzaro, Italy; \\ michiprov@hotmail.it (M.P.); andreucci@unicz.it (M.A.) \\ * Correspondence: arturi@unicz.it; Tel.: +39-0961-3647072
}

Citation: Pelle, M.C.; Provenzano, M.; Zaffina, I.; Pujia, R.; Giofrè, F.; Lucà,

S.; Andreucci, M.; Sciacqua, A.;

Arturi, F. Role of a Dual

Glucose-Dependent Insulinotropic

Peptide (GIP)/Glucagon-like

Peptide-1 Receptor Agonist

(Twincretin) in Glycemic Control:

From Pathophysiology to Treatment.

Life 2022, 12, 29. https: / / doi.org/

10.3390/life12010029

Academic Editor: Juei-tang Cheng

Received: 15 November 2021

Accepted: 21 December 2021

Published: 25 December 2021

Publisher's Note: MDPI stays neutral with regard to jurisdictional claims in published maps and institutional affiliations.

Copyright: (C) 2021 by the authors. Licensee MDPI, Basel, Switzerland. This article is an open access article distributed under the terms and conditions of the Creative Commons Attribution (CC BY) license (https:// creativecommons.org/licenses/by/ $4.0 /)$.

\begin{abstract}
Glucagon-like peptide-1 (GLP-1) and glucose-dependent insulinotropic polypeptide (GIP) are two gut hormones, defined incretins, responsible for the amplification of insulin secretion after oral glucose intake. Unlike GLP-1, GIP has little acute effect on insulin secretion and no effect on food intake; instead it seems that the GIP may be an obesity-promoting hormone. In patients with type2 diabetes mellitus (T2DM) some studies found a downregulation of GIP receptors on pancreatic $\beta$ cells caused by hyperglycemic state, but the glucagonotropic effect persisted. Agonists of the receptor for the GLP-1 have proven successful for the treatment of diabetes, since they reduce the risk for cardiovascular and renal events, but the possible application of GIP as therapy for T2DM is discussed. Moreover, the latest evidence showed a synergetic effect when GIP was combined with GLP-1 in monomolecular co-agonists. In fact, compared with the separate infusion of each hormone, the combination increased both insulin response and glucagonostatic response. In accordance with theseconsiderations, a dual GIP/GLP-1receptor agonist, i.e., Tirzepatide, known as a "twincretin" had been developed. In the pre-clinical trials, as well as Phase 1-3 clinical trials, Tirzepatideshowedpotent glucose lowering and weight loss effects within an acceptable safety.
\end{abstract}

Keywords: hyperglycemia; GIP; twincretin; pathophysiology; therapeutics

\section{Introduction}

The discovery of the incretin dates to 1929 due to the work of La Barre [1], but the true pioneers of the incretin concept were Bayliss and Moore 20 years earlier, when they hypothesized that the endocrine pancreas secretion was regulated by hormones contained in the gut extracts [2,3]. Incretin was forgotten for three decades until the discovery by McIntyre [4] that stated that intestines released some humoral substances, after glucose ingestion, that helped to promote $\beta$-cellular secretion of insulin, followed by the introduction by Unger and Eisentrout of the concept of "entero-insular axis" [5].

The two best studied incretins are glucagon-like peptide-1 (GLP-1) and glucosedependent insulinotropic polypeptide (GIP). GLP-1 is a 30-amino acid peptide, secreted from intestinal L cells in response to meal ingestion [6,7]. GIP, originally isolated from porcine intestine, is a 42-amino-acid hormone secreted from K-cells of the upper small intestine [8,9].

Both GLP-1 and GIP are inactivated by DPP-4, resulting in a short half-life [10]. The GLP-1 receptor is expressed in the pancreas, gastrointestinal tract, kidney, heart, and brain [11]. The insulinotropic property, gluconostatic effect during hyperglycemia, and normoglycaemic state of GLP-1 have been well demonstrated. Moreover, this hormone has 
several extrapancreatic properties; in fact GLP-1 promotes satiety, reduces food intake, and slows gastric emptying [12].

In 2005, the FDA approved the first GLP-1 receptor agonists, exenatide, which followed with several studies demonstrating their efficacy and safety in T2DM subjects. In fact, this pharmacological class improved glucose homeostasis and reduced body weight [13], but interestingly, large cardiovascular outcome trials showed that GLP-1 agonists were not only well tolerated, but also reduced the risk of cardiovascular and renal outcomes in T2DM patients [14].

Although GIP was the first to be isolated, for many years its function was unclear. Unlike GLP-1, some studies demonstrated that the glucanotropic effects of GIP was present in the normoglycaemic and hypoglycaemic state and was unclear in the hyperglycaemic state [15].

During the chronic hyperglycaemic state, GIP receptors on pancreatic $\beta$ cells are down regulated, but the insulinotropic effect can be restored by improving glycemic control [16]

Only in recent years has scientific research focused its interest on the synergistic action of GLP-1 and GIP. In vitro and in vivo preclinical studies have demonstrated that co-infusion of GLP-1 and GIP leads to improvement of glucose control and bodyweight regulation [17], compared with separate administration of each hormone. These findings have been confirmed in human studies.

Based on promising data, a dual GIP/GLP-1 receptor agonist, named "twincretin", has been developed. There is emerging evidence on two molecules, NNC0090-2746 and LY3298176. The first molecule, developed by Novo Nordisk, is a fatty-acylated GIP/GLP1 dual agonist, showed to improve glycated hemoglobin and to reduce bodyweight in patients with T2DM, compared to liraglutide in a Phase 2 clinical trial [18], (whereas no Phase 3 clinical trials are currently ongoing). The second molecule (developed by Eli Lilly and Company; Indianapolis, IN, USA), has passed Phase 1 and Phase 2 trials, and a Phase 3 clinical trial program (SURPASS Program) of this dual GIP/GLP-1 RA, named tirzepatide is ongoing [19], testing the long-term efficacy, safety, and cardiovascular outcomes of tirzepatide.

This review provides an overview regarding the effects of GIP/GLP-1 receptor agonist on the improvement of glucose control in T2DMpatients, as well as the emerging and relevant findings derived from preclinical and clinical studies focused on the Phase 3 clinical trial program of tirzepatide.

\section{GIP Physiology: Similarities and Differences versus GLP-1}

Glucose-dependent insulinotropic polypeptide (GIP) was the first gut hormone [10] to be isolated in 1970-1975 [20]. GIP and glucagon-like peptide-1 (GLP-1), the second intestinal hormones discovered, are called incretins [21], as they improve the insulin response after oral glucose administration, compared to that obtained following intravenous administration $[1,22,23]$. GIP is a 42 -amino acid polypeptide secreted from enteroendocrine $\mathrm{K}$-cells that are found in the small intestinal epithelium $[24,25]$. It originates from the posttranslational processing of pre-pro-GIP and its structure is similar to secretin, glucagon, vasoactive intestinal peptide, and growth hormone-releasing factor [8]. K-cells express a variant of sodium-coupled glucose transporter-1 (SGLT-1), that works as a sensor for incretin secretion after oral ingestion of nutrients, such as glucose, amino acids, and longchain fatty acids [26,27]. The half-life of GIP is 5 to $7 \mathrm{~min}$ [28], since it is rapidly inactivated by the ubiquitous enzyme dipeptidyl peptidase 4 (DPP-4) [29] that cuts alanine and proline residues in position 2 of the N-terminus in peptide chains [30]. GIP receptors (GIPRs) are found in several tissues, such as adipose tissue, bone, adrenal cortex, heart, pituitary, and cerebral cortex, hippocampus, and olfactory bulb [31], but their role at many of these sites is uncertain [20]. As previously mentioned, the incretin effect, for which following the ingestion of food the K-cells secrete the GIP, which by binding to its receptor located on the pancreatic $\beta$ cells increases insulin secretion in a glucose-dependent manner. This mechanism includes the increase of cAMP, inhibition of $\mathrm{K}_{\mathrm{ATP}}$ channels, increases in in- 
tracellular $\mathrm{Ca}^{2+}$, and stimulation of exocytosis [32,33]. In addition, GIP stimulates the transcription of $\beta$-cell insulin gene [34]. In the central nervous system, GIP could stimulate neural cell proliferation and modify behavior [35]. On adipose tissue, GIP has anabolic properties, activating fatty acid synthesis and reducing glucagon-mediated lipolysis [10]. Regarding bone, GIP induces proliferation of osteoblasts and inhibits osteoclastic bone resorption [36]. Finally, GIP decreases gastrin dependent acid secretion from the parietal cells of the stomach [37], but only at supraphysiologic doses [38].

Incretins have similar, but not identical, biological characteristics. First, the secretion of GIP and GLP-1 following the ingestion of nutrients is different. In fact, for the secretion of GIP their absorption is necessary, while for GLP1 their presence in the lumen would seem to be sufficient $[39,40]$. GIP is secreted from K-cells of the proximal small intestine (duodenum and jejunum) $[8,41]$, while GLP-1 secretion from L-cells of the small and large intestine (distal ileum and colon) [42] following an introduction of carbohydrates, triglycerides, protein, or amino acids. An important exception is glutamine, which is a specific stimulator for GLP-1 [43]. It is important to underline that the GIP response does not depend on the quantity of the food ingested as on the composition [44] (Figure 1).

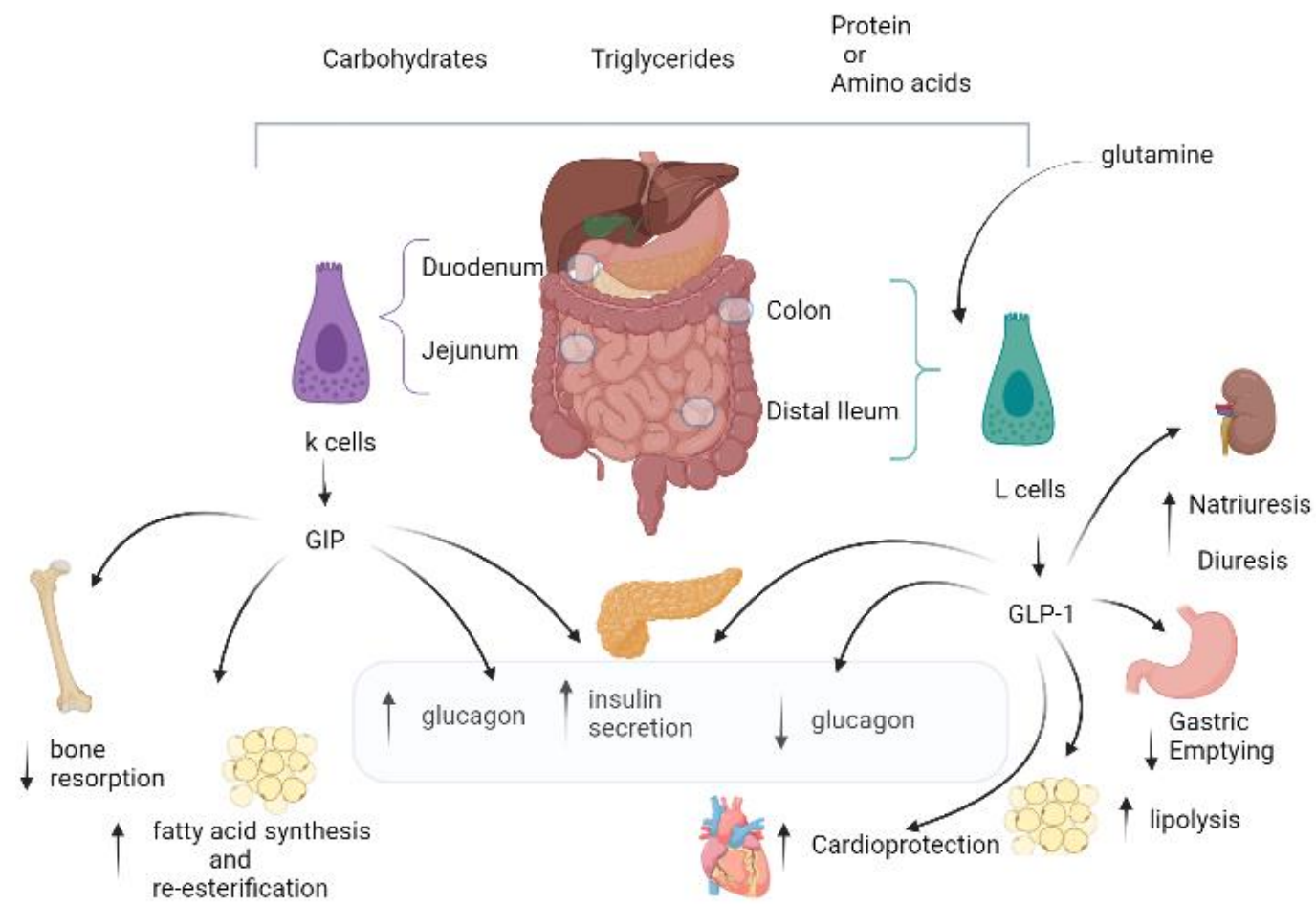

Figure 1. GIP and GLP-1: similarities and differences. GIP is secreted from K-cells of the proximal small intestine (duodenum and jejunum), while GLP-1 is secretedfrom L-cells of the small and large intestine (distal ileum and colon), following an introduction of carbohydrates, triglycerides, protein or amino acids. An important exception is glutamine, which is a specific stimulator for GLP-1. GIP and GLP-1determine insulin secretion in a glucose dependent manner. The actions of GLP-1 and GIP on glucagon secretion are differing, GLP-1 suppresses glucagon during hyperglycemia, but not at a normal fasting plasma glucose concentration, whereas GIP can stimulate glucagon secretion at fasting glycemic, during hypoglycemia, and hyperglycemia. Regarding adipose tissue, GLP-1 stimulates lipolysis, while GIP leads an accumulation of body fat.

The half-life of GIP and bioactive GLP-1 is only a few minutes $[45,46]$ since they are inactivated by DPP-4 [47]. Both GLP-1 and GIP receptors are expressed on pancreatic alpha and $\beta$-cells [48-51]. Moreover, GIP receptors are found on $\delta$ and PP cells [45]. GIP and GLP-1 exercise their effects by GIP and GLP-1 receptors [49,52-58], respectively, that are $\mathrm{G}$-protein coupled receptors expressed on pancreatic $\beta$-cells. Their mechanism involves the 
activation of adenylate cyclase/protein kinase $\mathrm{A}$ and cascades of phospholipase $\mathrm{C} /$ protein $\mathrm{C}$ so that binding of GIP to its receptor increases intracellular cAMP levels with a downstream increase in calcium ion concentration and insulin exocytosis [29]. This determines insulin secretion in a glucose dependent manner [10,59]; however, if they are not stimulated by the GIP they are internalized and recycled [60,61] (Figure 2).

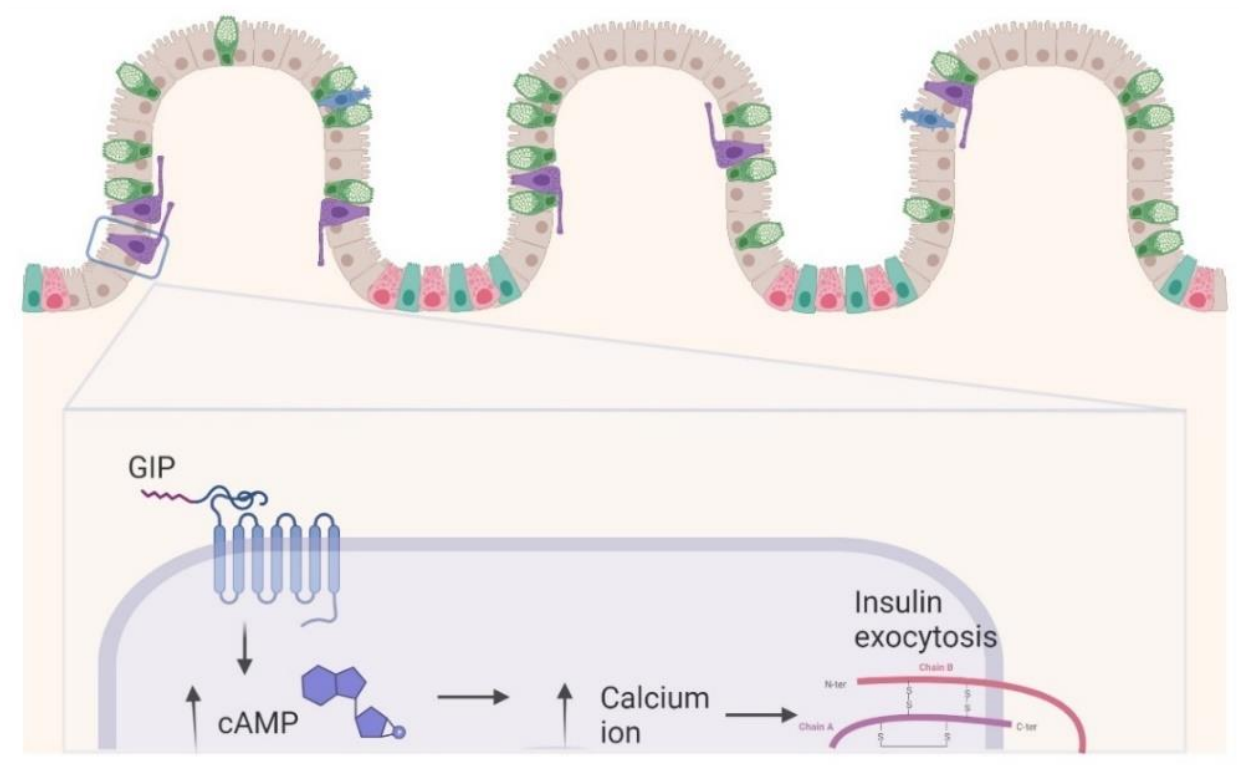

Figure 2. GIP receptors.GIP receptors (GIPRs) found in a variety of tissues are class-II G-protein coupled receptors whose mechanism involves the activation of adenylate cyclase/protein kinase A and cascades of phospholipase C/protein C so that binding of GIP to its receptor increases intracellular cAMP levels with a downstream increase in calcium ion concentration and insulin exocytosis; however, if they are not stimulated by the GIP they are internalized and recycled.

Moreover, they improve $\beta$-cell proliferation and survival [62]. The actions of GLP1 and GIP on glucagon secretion are different, since GLP-1 suppresses glucagon [63] during hyperglycemia [64-66], but not at a normal fasting plasma glucose concentration [65]. GIP can stimulate glucagon secretion at fasting glycemic [67], during hypoglycemia, and hyperglycemia $[64,68]$. There is a close relationship between adipose tissue and GIP; fats strongly augment GIP secretion [69,70] and GIP levels are high in obese T2DM patients [71]. Although GLP1 stimulates lipolysis [10,71-77], GIP leads to the accumulation of body fat through fatty acid synthesis and re-esterification, augmentation of integration of fatty acids into triglycerides, increased synthesis of lipoprotein lipase, and reduction of lipolysis. GIP, and perhaps to a lesser extent GLP-1, which does not present clear evidence of bone metabolism, act on bone remodeling through the effects on osteoclasts and osteoblasts [43]. Incretins have been shown to indirectly affect hepatic and muscle metabolism, specifically through changes in circulating concentrations of insulin and glucagon [31,78-80]. Receptors for incretins found in the brain involved regulating feeding and energy expenditure. Furthermore, they are involved in synaptic plasticity [31,81], memory functions, and emotional responses, with the possibility of beneficial effects for a series of neurodegenerative disorders [81,82]. The effect of incretins on the gastrointestinal tract is opposite; GLP-1 slows gastric emptying [83-85], whereas this effect is not confirmed for GIP [86]. GIP and GLP1 receptors are expressed in the cardiovascular system $[33,79,80]$, where for the former the physiologic actions in these tissues are not known, while for the latter the beneficial action is known in terms of improving myocardial function and endothelial dysfunction, as well as increasing heart rate [10]. 


\section{The Dual GIP/GLP-1 Mechanisms}

Although the GIP was the first to be isolated, for many years its function was unclear in the hyperglycaemic state; therefore, for this reason it was not used as a target for diabetic therapy, unlike GLP-1. Only recently scientific research has focused its interest on the synergistic action of GLP-1 and GIP, and as such several studies have been carried out and some are still ongoing.

GIP and GLP-1 receptors are both found in pancreatic $\beta$ cells. It is hypothesized that dual agonists can improve insulin secretion directly. Furthermore the reduction of the hyperglycemic state reduces the resistance to GIP $[18,87]$. Both receptors are present in the metabolic centers of the central nervous system, while only the GIP receptors are present in the adipose tissue, therefore their activation is assumed to be complementary to that of GLP-1 [88]. The co-activation can directly and indirectly improve insulin sensitivity, with an addictive effect. As will be discussed later, the combined infusion of GIP and GLP-1 produces a more important gluconostatic effect and enhanced insulin secretion than the single administration [89] (Figure 3).

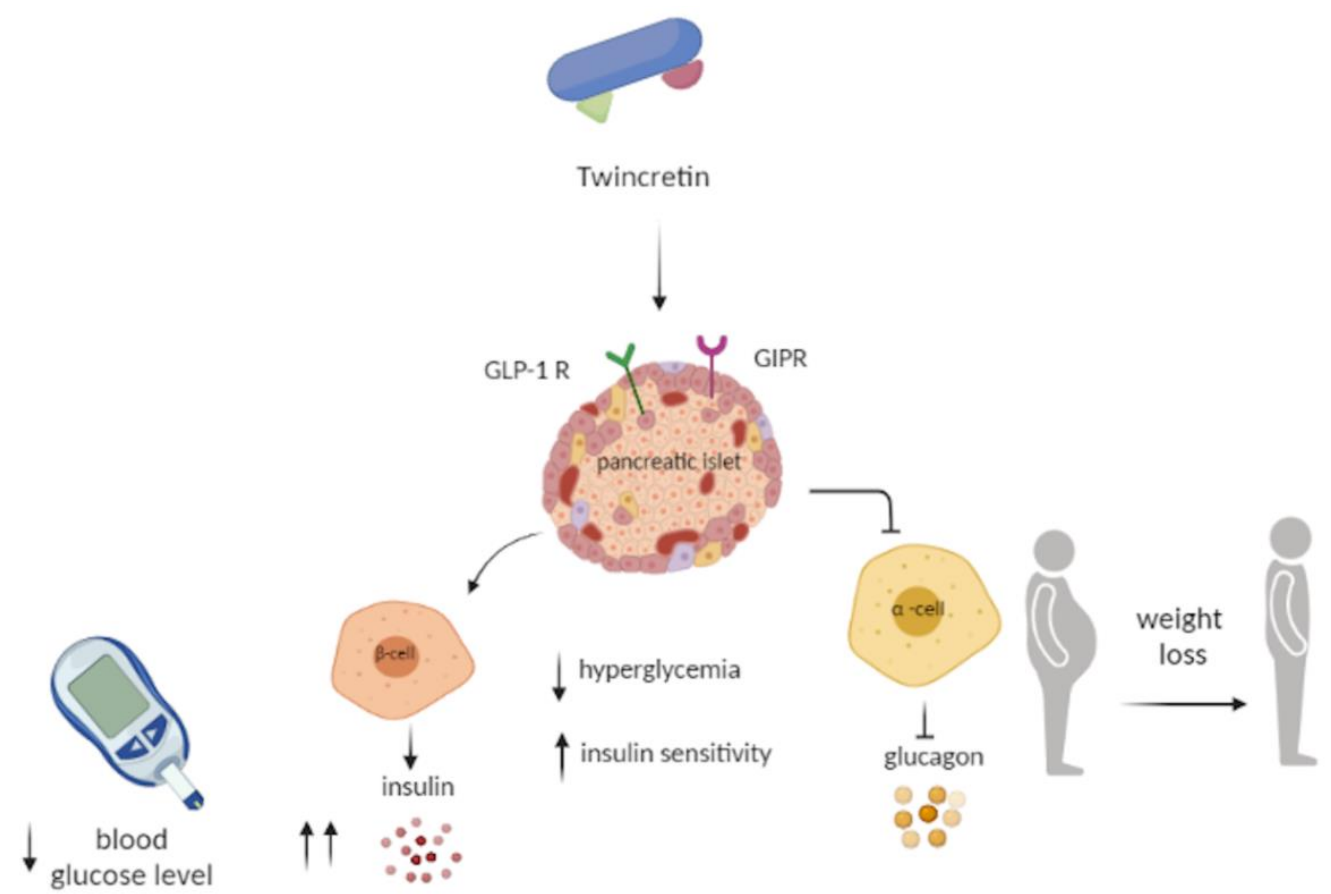

Figure 3. The dual GIP/GLP-1 mechanisms. GIP and GLP-1 receptors are both found in pancreatic $\beta$ cells; the co-activation produces a more important gluconostatic effect and enhances insulin secretion than the single administration. Moreover, it could ameliorate food intake, body weight, and fat mass.

The molecular mechanism of unimolecular incretins is not elucidated; however, they appear to correct insulin resistance due to adiposity and insulin secretion deficit. To understand whether the residual glucagon activity is a therapeutic target, fibroblast growth factor 21 (FGF21) and ketone bodies were measured as plasma markers indicative of chronic glucagon agonism. However, the administration of the dual incretin did not increase circulating FGF21 levels in vitro [90], while insulin secretion was greater than a single peptide. Animal studies demonstrated that co-stimulation could ameliorate food intake, body weight, and fat mass [90]. Furthermore, in human studies the main effect was increased insulin secretion [91] and inhibition glucagon one [89].

\section{In Vitro Studies}

Several in vitro studies have shown that the simultaneous administration of GIP and GLP-1 exert an additive effect on the processes that influenced the intracellular levels of cyclic adenosine monophasfate (cAMP) [92]. 
Gallwitz et al., (1993) proved an additive effect of GIP and GLP-1 on cyclic AMP production in RINm5F insulinoma cells (rat $\beta$-cells), demonstrating that the adenylate cyclase was influenced by signals produced from both receptors [93]. Later, Delmeire et al., (2004), explored the impact of GLP-1, GIP, or their combination on secretory function of the healthy rat $\beta$ cell. This cell culture was performed for $24 \mathrm{~h}$, added with either glucose alone or glucose with GLP-1, exendin-4, or GIP. They showed that GLP-1 acutely stimulated cellular cAMP production and enhanced glucose-stimulated insulin secretion, whereas prolonged contact with GLP-1 resulted in a time-dependent decrease in the cAMP. Furthermore, their data proved for the first time that a mixture of GLP-1 and GIP at physiological concentrations influenced the capacity to respond to later secretory stimuli independently of insulin content [94].

Lupi et al., (2010), tested the effects of acute ( $45 \mathrm{~min}$ ) or prolonged (2 days) exposure to GLP-1 or GIP, alone or in combination on human pancreatic islets, that were obtained from non-diabetic and type 2 diabetic donors. $\beta$-cells were exposed acutely $(45 \mathrm{~min})$ with glucose, with or without the addition of GLP-1, GIP (in increasing doses), or a combination of GLP-1 and GIP. Furthermore, they were incubated for $48 \mathrm{~h}$ either with or without the addition of GLP-1, GIP, or a combination of both, followed by acute glucose stimulation. The authors demonstrated that GLP-1 and GIP have beneficial effects on insulin secretion both on-diabetic and type 2 diabetic human islets with acute or prolonged exposure to GLP-1 and GIP. In fact, pre-incubation with either GLP-1, GIP, or a combination of the two caused a $20-30 \%$ increase of insulin secretion. After prolonged exposure, the incretins administered together, therefore, exhibited synergistic action on both insulin synthesis and secretion, as well as effects on the genes associated with $\beta$-cell differentiation and survival, compared to the effects of individual peptides [95].

Furthermore, in vitro studies have documented that GIP may enhance the actions of GLP-1 by acting on the expression of both GLP-1R and GIPR. Incretin receptors belong to those coupled to $G$ proteins, which function as monomers, heterodimers, or homodimers. Some $[96,97]$ studies described that GLP-1R/GIPR heterodimer offered a reduced response to GLP-1 stimulation [98-100]. This conformation can be induced by GLP-1, while reversed by GIP [99].

\section{Animal Studies}

Animal studies did not provide unambiguous results. Certain studies demonstrated that a co-administration in ob/ob mice of GLP-1analogues, and GIP improved hypoglycemic, insulinotropic, and weight-reducing actions compared to the individual incretins [101-107].

Gault VA et al., (2011), evaluated the in vivo hypoglycemic effects of a Liraglutide and NAcGIP (Lys37Myr), a simple combination of Liraglutide plus N-AcGIP, or LiraAcGIPpreparation (Lira-AcGIP) in healthy male Swiss TO mice and obese diabetic (ob/ob) mice in two phases. During the first, the acute (after $4 \mathrm{~h}$ from injection) glucose lowering and insulinotropic effects of incretins were evaluated on Swiss TO mice. Liraglutide and N-AcGIP established an important glycemic control, but the association of Liraglutide plus N-AcGIPdid not present a significant effect when compared to Liraglutide or N-AcGIP administered alone. Instead, the Lira-AcGIP preparation demonstrated an enhanced glycemic control compared to Liraglutide, N-AcGIP, and the simple combination of Liraglutide and N-AcGIP (17-45\% reduction; $p<0.05-p<0.001)$. Next, the second subchronic phase of in vivo study was conducted on obese diabetic ob/ob mice, during which Lira-AcGIP, Liraglutide, or N-AcGIP were administered once daily over 21 days. Liraglutide and Lira-AcGIP significantly reduced food intake, but only Lira-AcGIP reduced body weight [101].

Pathak NM et al., (2018) [105], compared the metabolic effects of the peptide, Nac(D-Ala2)GIP/GLP-1-exe, a 56-amino acid hybrid peptide containing amino acids that allow it to bind to GIP and GLP-1 receptors, and with characteristics of exendin-4, known 
for enhanced metabolic stability and reduced clearance with respect to (D-Ala2) GIP, or exenin-4 therapy alone or in combination, administered twice daily.

Initially, acute effects of N-ac(D-Ala2) GIP/GLP-1-exe on glucose and insulin concentrations were evaluated demonstrating an evident $4(p<0.001)$ and $8(p<0.05)$ hours post-injection benefit on reducing serum glucose and improving insulin secretory compared to controls. Next, they proceeded to evaluate metabolic effects on high-fat-fed (HFF) mice of chronic treatment with $\mathrm{N}-\mathrm{ac}(\mathrm{D}-\mathrm{Ala} 2) \mathrm{GIP} / \mathrm{GLP}-1-\mathrm{exe}$, exendin-4 alone, and in combination with (D-Ala2)GIP, administrating twice daily over 28 days. This demonstrated a reduction of body weight, related with the loss of total body fat, while no change in lean body mass was documented, improving $\mathrm{HbA1c}$, non-fasting blood glucose levels, and lipid profile, most likely due to enhanced insulin and $\beta$-cell insulin sensitivity when compared to the control group (saline). The hybrid peptide was able to act on the memory impairment associated with obesity-diabetes by improving it. Notably, the results of the second phase of this study obtained N-ac(D-Ala2) GIP/GLP-1-exe were analogous to (D-Ala2)GIP or exenin-4 therapy alone or in combination [106].

Furthermore, other studies demonstrated that the incretins together improved energy consumption and food intake in mice [101,108,109].

Irwin et al., (2007), studied the effects ofexendin-4 therapy administered once daily compared to saline for 12 days on a total of 14 HFF mice, followed by a further 12 days during which N-AcGIP was added. They demonstrated that exendin- 4 caused a significant $(p<0.05)$ reduction in food intake during days 1 and 3 of the first phase of this study, while $\mathrm{N}-\mathrm{AcGIP}$ had no effect on food intake when administered alone. Instead, the combined administration of GIP and GLP-1R agonist resulted in an increase in weight loss compared to GLP1R agonist alone, but no additional benefits in regulating glucose homeostasis [109].

However, other studies have shown that their simultaneous administration did not determine benefits when compared to the intake of incretins alone [110-112].

Irwin N. et al., (2007), studied the effects of sub-chronic (14 days) intra-peritoneal administration of N-AcGIP, exendin(1-39)amide, or the combination of both peptides or glucose in adult ob/ob mice. Ob/ob mice received intra-peritoneal injection of glucose alone $(18 \mathrm{mmol} / \mathrm{kg}$ body weight) or in combination with GIP, GLP-1, N-AcGIP, or exendin(1-39)amide. N-AcGIP alone or in combination with exendin(1-39)amide significantly decreased non-fasting plasma glucose $\operatorname{HbA1c}(p<0.05)$ and improved glucose tolerance, but no significant effect on food intake or body weight between these groups was identified [110].

Killion et al., (2018), developed a mouse anti-murine monoclonal GIPR antibody (muGIPR-Ab) and an anti-human antagonist antibody(hGIPR-Ab). They treated GIPR knockout mice protected against diet induced obesity (DIO) with muGIPR-Ab or nonneutralizing GIPR antibody (CTL-Ab) for 45 days, resulting in a greater reduction in body weight of the muGIPR-Ab group, compared to control group. Furthermore, fasting blood glucose and serum insulin were reduced in the muGIPR-Ab treated group when compared to the control, while no enhancement in glucose tolerance was documented. Further, muGIPR-Ab, liraglutide, or a combination of both were administered to DIO mice, reaching a $23.5 \%$ of weight loss in the combination group. This last group achieved a reduction in food intake, as well as in the group with liraglutide alone. Next, they administered hGIPR-Ab, dulaglutide, a combination of both, or vehicle on nonhuman primates (NHPs) obtaining in the combination group a greater body weight reduction and a reduction of food intake, when compared to single treatments [113].

The rationale for these conflicting results could be due to the dose or desensitization of GLP-1R in the ob/ob mice used in the studies $[110,114]$.

Finally, in these in vivo studies, the role of glucagon remains obscure, since mostly the levels have not been measured [110]. 


\section{In Human Studies}

To investigate individual and combined contributions of GLP-1 and GIP, Nuck et al., (1993), [91] administered both molecules in seven healthy volunteers, alone and combined, during an IV glucose infusion "isoglycemic" after an oral glucose tolerance test $(50 \mathrm{~g} / 400 \mathrm{~mL})$. The $\beta$-cell response after administration of glucose IV alone and after single infusions of GLP-1 (7-36) amide (0.3 pmol $/ \mathrm{kg} / \mathrm{min})$ and GIP (1 pmol $/ \mathrm{kg} / \mathrm{min})$ was similar. Instead, when the two hormones were infused together, insulin secretion increased, thus demonstrating an additive effect. In another study, to establish the insulinotropic effect of two hormones, Elhai et al. [89] infused GLP-1 (7-37) amide and GIP into healthy subjects, as well as another group with diabetes mellitus. Different from GIP, during euglycemia, in the healthy subjects GLP-1 (7-37) stimulated insulin release. During hyperglycemia, induced with a clamp, insulin secretion increased when the hormones were co-infused, compared to the infusion of individual molecules. Moreover, incretins co-infusion induced a significant glucagonostatic effect, compared to separately infusion of glucose infusion alone.

In another study, a combination of synthetic GIP, synthetic GLP-1 (7-36) amide, and synthetic human glucagon-like peptide-2 (GLP-2) infused into ten subjects with diabetes, during an IV glucose infusion matching an OGTT, glucagon, and insulin secretion were measured. Mean body mass index (BMI) was $33.2 \mathrm{~kg} / \mathrm{m} 2$ and mean $\mathrm{HbA1c}$ level was 6.8\%; nine subjects were treated with metformin, or one metformin combined with sulphonylurea. In this study, GLP-1 infusion suppressed glucagon secretion, while GIP alone promoted glucagon response; when these hormones were administered together glucagon did not change. Insulin secretion increased during co-infusion, compared with GIP alone or GLP2 alone, but not with GLP-1 alone; this result highlighted the lack of GIP stimulus on insulin release in patients with diabetes. Moreover, this study emphasized that GIP increased the inappropriate glucagon secretion after orally ingested glucose in subjects with T2DM [115].

Dousi et al., (2009) [116] included in their study six obese male patients with diet controlled T2DM $(\mathrm{HbA} 1 \mathrm{c}<8 \%)$ and six healthy lean male subjects. All participants received an infusion of synthetic human GIP $(2 \mathrm{pmol} / \mathrm{kg} / \mathrm{min})$ combined with GLP-1 $(1 \mathrm{pmol} / \mathrm{kg} / \mathrm{min})$ for $4 \mathrm{~h}$. After which, co-infusion insulin was detected. In healthy subjects, insulin increased after co-infusion compared with GLP-1, GIP, or placebo (saline infusion) infusion alone. Instead, in subjects with T2DM the insulin secretion did not increase when compared with GLP-1 infusion alone, but there was an increase when compared with GIP and placebo administration, emphasizing the reduced insulinotropic effect of GIP in patients with diabetes. Moreover, in this study, energy expenditure (measured with indirect calorimetry), appetite rating, and the desire to eat were evaluated. Healthy subjects reported a higher hunger score during GIP infusion, only when compared with the placebo, whereas patients with diabetes, during co-infusion, reported a stronger desire to eat. GIP infusion determined a reduction in energy expenditure in the healthy, but not in subjects with T2DM. The limit of this study was the poor simple size, particularly in regards to the results on food intake and appetite.

In another study, the authors evaluated in two protocols "early" (0-20 min) and "late" (20-120 $\mathrm{min}$ ) phase insulin and C-peptide responses to GLP-1 and GIP stimulation, in patients with T2DMmatching healthy subjects. GLP-1increased during the "late phase" insulin secretion to levels similar to those observed in healthy subjects, but this result was not observed with GIP. Then, in subjects with diabetes, a lack of GIP amplification of the late phase insulin response to glucose was observed [117].

In another study, 12 fasting patients with T2DMwere included; they had a mean $\mathrm{HbA1c}$ of $7.3 \%$ and a mean BMI of $30 \mathrm{~kg} / \mathrm{m}^{2}$. All participants received an infusion of human synthetic GIP (4 pmol $/ \mathrm{kg} / \mathrm{min})$ and GLP-1 $(1.2 \mathrm{pmol} / \mathrm{kg} / \mathrm{min})$ for $6 \mathrm{~h}$. Blood glucose, plasma insulin, C-peptide, glucagon, GIP, GLP-1, and free fatty acids (FFA) were determined during the experiment. In this randomized-controlled trial, GIP was unable to increase the insulinotropic effect of GLP-1 during co-infusion. In fact, comparing GLP-1 alone administration, the co-infusion resulted in similar blood glucose and insulin secretion rates 
in type 2 diabetes, but the suppression of plasma glucagon by GLP-1 was antagonized by GIP [118].

In conclusion, from the data provided by the GIP and GLP-1 co-infusion studies in humans, it is evident that the short-term administration of both hormones acutely increased insulin secretion and decreased blood glucose levels in healthy subjects, but not in diabetic, if compared with single GLP-1 infusion.

The lack of insulinotropic effects of GIP in type 2 diabetes, as seen in acute infusion studies, could depend on hyperglycemia. In fact, long-term glycemic control can improve the effectiveness of insulinotropic, but chronic treatment with GIP agonists alone has not been tested in humans $[118,119]$.

Moreover, human studies evidenced that the GIP receptors was down regulated in adipose tissue in insulin-resistant states, but acute infusion of GIP under hyperinsulinism and hyperglycemia conditions promoted adipose tissue glucose uptake and triglyceride hydrolysis [74,104,120,121].

\section{Twincretin}

Considering that the co-infusion of GLP-1 and GIP receptor agonists showed an additive effect on glucose and bodyweight control, recent studies on GLP-1R/GIPR dual agonists have been started. This unimolecular co-agonist is named "twincretin".

In study of Finan et al., (2013) [90], unimolecular dual incretin was derived from an intermixed sequence of GLP-1 and GIP and administered into rodent models of obesity and diabetes and compared with placebo or equimolar doses of exendin-4. After one week of treatment, the co-agonist improved insulin sensitivity, corrected hyperglycemia, and lowered body weight. The half-life of this molecule was prolonged either by acylation with a 16-carbon acyl chain or by attaching to a polyethylene glycol (PEG). Both versions of the co-agonists administered into $d b / d b$ mice, ZDF rats, and into primates (cynomolgus monkeys) and demonstrated that a reduced body weight and lowered fasting glycemic in three weeks of treatment. In monkeys, dual agonist was compared with liraglutide. Instead, in healthy humans the co-agonist compared with the placebo during OGTT and showed amelioration of insulin levels and glucose tolerance. Then, GLP-1R/GIPR dual agonist corrected adiposity-induced insulin resistance and pancreatic insulin deficiency [12,92].

The beneficial effect of GLP-1R/GIPR dual agonist was confirmed in clinical trials. NNC0090-2746 (developed by Novo Nordisk) is a fatty-acylated GIP/GLP-1 dual agonist; in Phase 1 trials it achieved steady-state concentration within one week by daily dosing [122]. Once-daily doses of up to $2 \mathrm{mg}$ were well tolerated [123]. After two weeks of treatment at doses $>0.75 \mathrm{mg}, \mathrm{HbA1c}$, fasting, and postprandial plasma glucose decreased [122]. NCT02205528 was a Phase 2 clinical trial of NNC0090-2746, and was designed as a multicenter, randomized, double-blind, parallel group, placebo-controlled trial with open-label comparison, performed in patients with T2DM inadequately controlled with metformin (108 participants, 12 withdrew prematurely from the trial, 96 completed). The trial was performed in 12-weeks, investigators administered $1.8 \mathrm{mg}$ of NNC 0090-2746, compared with $1.8 \mathrm{mg}$ of liraglutide. Patients had a mean age of 54.8 years, the mean duration of diabetes was 8.0 years, the mean $\mathrm{HbA} 1 \mathrm{c}$ was $8.3 \%$, and the mean body mass index was $33.0 \mathrm{~kg} / \mathrm{m} 2$. It showed improving glycated hemoglobin ( $-0.96 \%$ vs. placebo) and reducing bodyweight $(-1.67 \%$ vs. placebo) in patients with type 2 diabetes. NNC0090-2746 reduced $\mathrm{HbA1c}$ similarly to the group treated with liraglutide, whereas the bodyweight reduction was significantly greater than that of liraglutide $(-1.17 \%$ vs. placebo). Treatment with NNC0090-2746 was generally safe and well tolerated [18].

A 26-week treatment of GLP-1R/GIPR dual agonist, LY3298176 (Eli Lilly and Company; Indianapolis, IN, USA), was also tested. This trial was a double-blind, randomized, Phase 2 study, performed in patients with type 2 diabetes, received either onceweekly subcutaneous LY3298176 (1 mg, $5 \mathrm{mg}, 10 \mathrm{mg}$, or $15 \mathrm{mg})$, dulaglutide $(1,5 \mathrm{mg})$, or placebo [19]. Analysis included 316 participants. At baseline, mean $\mathrm{HbA}_{1 \mathrm{c}}$ was $8.1 \%$, BMI was $32.6 \mathrm{~kg} / \mathrm{m}^{2}$, and age was 57 years, the mean duration of diabetes was 9.0 years. 
LY3298176 significantly reduced $\mathrm{HbA1c}$ in a dose-dependent manner $(1 \mathrm{mg},-1.06 \% ; 5 \mathrm{mg}$, $-1.73 \%$; $10 \mathrm{mg},-1.89 \%$; $15 \mathrm{mg},-1.94 \%)$ when compared with $1.5 \mathrm{mg}$ of GLP-1R dulaglutide $(-1.21 \%)$ and placebo $(-0.06 \%)$, reduced bodyweight $(1 \mathrm{mg},-1.96 \mathrm{~kg} ; 5 \mathrm{mg}$, $-4.62 \mathrm{~kg} ; 10 \mathrm{mg},-6.88 \mathrm{~kg} ; 15 \mathrm{mg},-8.67 \mathrm{~kg})$ when compared with dulaglutide $(-2.48 \mathrm{~kg})$ and placebo $(-0.40 \mathrm{~kg})$ [18]. There were no reports of severe hypoglycemia. Adverse effects were similar to dulaglutide, and above all, regarding gastrointestinal adverse events, that was dose-related (23.1\% for $1 \mathrm{mg}$ LY3298176, 32.7\% for $5 \mathrm{mg}$ LY3298176, 51.0\% for $10 \mathrm{mg}$ LY3298176, and 66.0\% for $15 \mathrm{mg}$ LY3298176, 42.6\% for dulaglutide, 9.8\% for placebo [19].

\section{Tirzepatide, a Dual GIP/GLP-1 Receptor Agonist: Efficacy in Phase 3 Clinical Trials}

Based on promising results from Phase 1 and 2 clinical trials, a Phase 3 clinical trial program of the dual GIP/GLP-1 RA, tirzepatide (LY3298176, Eli Lilly and Company, Indianapolis, IN), was started. Tirzepatide was a 39-amino acid linear synthetic peptide that shared19 amino acids with human GIP, conjugated to a C20 fatty diacid moiety via a linker connected to the lysine residue at position 20. Due to the acylation technology, the half-life was prolonged and a once-weekly dosing regimen in humans was completed. Tirzepatide is a single molecule with agonist activity at both the GIP receptor (GIPR) and GLP-1R [124].

To date, the SURPASS program includes nine ongoing randomized controlled trials in patients with type2 diabetes: SURPASS 1 in monotherapy, SURPASS 2 versus semaglutide, SURPASS 3 versus degludec, SURPASS 4 versus glargine and established CV disease, SURPSS 5 basal insulin add-on, SURPASS AP- Combo versus glargine, and SURPASSCVOT.

SURPASS-1was a 40-week, double-blind, randomized, Phase 3 trial. Participants (705) were subjects with T2DMinadequately controlled by diet and exercise alone and assigned to receive once a week tirzepatide $(5,10$, or $15 \mathrm{mg})$, or a placebo. The mean baseline of $\mathrm{HbA}_{1 \mathrm{c}}$ was $7.9 \%$, of age was 54.1 years (SD 11.9), diabetes duration was 4.7 years, and of body-mass index was $31.9 \mathrm{~kg} / \mathrm{m}^{2}$. At 40 weeks, tirzepatide induced a dose-dependent decreasing of $\mathrm{HbA} 1 \mathrm{c}$ and bodyweight. Gastrointestinal events were the most frequent adverse effects, such as nausea (12-18\% vs. $6 \%$ ), diarrhea (12-14\% vs. $8 \%$ ), and vomiting (2-6\% vs. 2\%). Severe hypoglycemia was not reported [125].

SURPASS-2 was an open-label, 40-week, Phase 3 clinical trial.1879 patients enrolled and received tirzepatide at a dose of $5 \mathrm{mg}, 10 \mathrm{mg}$, or $15 \mathrm{mg}$, or semaglutide at a dose of $1 \mathrm{mg}$. At baseline, the mean $\mathrm{HbA} 1 \mathrm{c}$ was $8.28 \%$, the mean age was 56.6 years, and the mean weight was $93.7 \mathrm{~kg}$. Tirzepatide at all doses was non inferior and superior to semaglutide as regards to the mean change in theHbA1c; instead reductions in body weight were greater with Tirzepatide than with semaglutide $(p<0.001)$. The most common adverse events were gastrointestinal [126].

In another Phase 3 study, there were 1947 subjects enrolled with T2DM; at baseline mean $\mathrm{HbA}_{1 \mathrm{c}}$ of $8.17 \%$ (SD 0.91) and a mean weight of $94.3 \mathrm{~kg}$ (SD 20.1). Researchers have evaluated the efficacy and safety of tirzepatide versus titrated insulin degludec in subjects with T2DMinadequately controlled by metformin, with or without SGLT2 inhibitors. The SURPASS-3 findings showed that people with T2DM can obtain a better glycemic control with tirzepatide than with insulin degludec, while losing weight rather than gaining weight. A higher incidence of gastrointestinal adverse effects was reported in participants treated with tirzepatide, compared with those treated with degludec [127].

SURPASS-4 was an open-label global trial comparing the safety and efficacy of tirzepatide with titrated insulin glargine in 2002 people with T2DMwith an increased CV risk who were treated with metformin, a sulfonylurea, or an SGLT-2 inhibitor. Study participants had a mean duration of diabetes of 11.8 years, a baseline $\mathrm{HbA} 1 \mathrm{c}$ of $8.52 \%$, and a baseline weight of $90.3 \mathrm{~kg}$. More than $85 \%$ of participants had a history of cardiovascular diseases. The highest dose of tirzepatide led to a significant $\mathrm{HbA1c}$ reduction at 52 weeks [128].

SURPASS-5 was designed for comparing tirzepatide versus the placebo as an addon therapy to titrated insulin glargine. In this randomized, Phase 3, double-blind trial, 
475 participants enrolled. Tirzepatide was associated with greater $\mathrm{HbA} 1 \mathrm{c}$ reductions and body weight reductions than placebo therapy. At 40 weeks, tirzepatide led to a reduction from baseline of $\mathrm{HbA} 1 \mathrm{c}$ of $2.59 \%$ with the highest dose and reduced body weight by $6.2 \mathrm{~kg}$, $8.2 \mathrm{~kg}$, and $10.9 \mathrm{~kg}$ with the three respective doses of active drug [129].

And finally, SURPASS AP-Combo and SURPASS-CVOT are ongoing.

SURPASS AP-Combo testing tirzepatide versus insulin glargine, over a 40-week period, in people taking metformin with or without a sulfonylurea of at least half the maximum dose (NCT04093752, estimated study completion in March 2022).

In SURPASS-CVOT tirzepatide is up against dulaglutide $1.5 \mathrm{mg}$, which has a confirmed cardioprotective effect. The investigators are assessing a three-point major adverse cardiovascular event endpoint (myocardial infarction, stroke, and cardiovascular death), over an estimated maximum of 54months (NCT04255433, estimated study completion in October 2024).

The results of the major studies and other informationof SURPASS Program are summarized in Table 1.

Table 1. Randomized controlled trials of tirzepatide in patients with T2DM.

\begin{tabular}{|c|c|c|c|c|c|}
\hline Study & Population & Sample Size & Intervention & $\begin{array}{l}\text { Primary } \\
\text { Outcome }\end{array}$ & Results \\
\hline SURPASS-1 (2021) & $\begin{array}{c}\text { T2DM } \\
\text { inadequately } \\
\text { controlled with } \\
\text { diet and exercise } \\
\text { alone }\end{array}$ & $\begin{array}{c}478 \\
\text { tirzepatide } 5 \mathrm{mg} \\
\quad(\mathrm{n}=121) ; \\
\text { tirzepatide } 10 \mathrm{mg} \\
\quad(\mathrm{n}=121) ; \\
\text { tirzepatide } 15 \mathrm{mg} \\
(\mathrm{n}=121) ; \text { placebo } \\
(\mathrm{n}=115)\end{array}$ & $\begin{array}{c}\text { Tirzepatide }(5,10, \\
\text { or } 15 \mathrm{mg}), \text { or } \\
\text { placebo }\end{array}$ & $\begin{array}{l}\text { To assess efficacy, } \\
\text { safety, and } \\
\text { tolerability } \\
\text { oftirzepatide } \\
\text { versus placebo, } \\
\text { and change from } \\
\text { baseline in } \\
\text { HbA1c } \\
\text { timeframe: } \\
\text { baseline week } 40\end{array}$ & $\begin{array}{l}\text { At } 40 \text { weeks, tirzepatide } \\
\text { induced a dose-dependent } \\
\text { decreasing of } \mathrm{HbA} 1 \mathrm{c} \\
\text { (mean } \mathrm{HbA}_{1 \mathrm{c}} \text { decreased } \\
\text { from baseline by } 1.87 \% \\
\text { with tirzepatide } 5 \mathrm{mg} \text {, } \\
1.89 \% \text { with tirzepatide } \\
10 \mathrm{mg} \text {, and } 2.07 \% \text { with } \\
\text { tirzepatide } 15 \mathrm{mg} \text { versus } \\
+0 \cdot 04 \% \text { with placebo), and } \\
\text { bodyweight loss ranging } \\
\text { from } 7.0 \text { to } 9.5 \mathrm{~kg} \text {. }\end{array}$ \\
\hline SURPASS-2 (2021) & $\begin{array}{c}\text { Patients with } \\
\text { T2DM treated } \\
\text { with unchanged } \\
\text { dose of } \\
\text { metformin > } \\
1500 \mathrm{mg} / \text { day for } \\
\text { at least } 3 \text { months } \\
\text { prior to } \\
\text { screening }\end{array}$ & $\begin{array}{c}1879 \\
\text { Patients are } \\
\text { randomized in a } \\
\text { 1:1:1:1 ratio, to } \\
\text { receive } \\
\text { tirzepatide at a } \\
\text { dose of } 5 \mathrm{mg} \text {, } \\
10 \mathrm{mg} \text {, or } 15 \mathrm{mg}, \\
\text { or semaglutide at } \\
\text { a dose of } 1 \mathrm{mg} .\end{array}$ & $\begin{array}{l}\text { Tirzepatide } \\
\text { (5 mg, } 10 \mathrm{mg} \text {, } \\
15 \mathrm{mg}) \text { versus } \\
\text { semaglutide once } \\
\text { weekly as } \\
\text { add-on therapy } \\
\text { to metformin }\end{array}$ & $\begin{array}{l}\text { To compare the } \\
\text { effect of the } \\
\text { tirzepatide to } \\
\text { semaglutide } \\
\text { onchange from } \\
\text { baseline in } \\
\text { HbA1c ( } 10 \mathrm{mg} \\
\text { and } 15 \mathrm{mg}) \text { at } \\
40 \text { week. }\end{array}$ & $\begin{array}{l}\text { Tirzepatide at all doses } \\
\text { was noninferior and } \\
\text { superior to semaglutide as } \\
\text { regards t othe mean } \\
\text { change in theHbA1c; } \\
\text { instead reductions in body } \\
\text { weight were greater with } \\
\text { tirzepatide than with } \\
\text { semaglutide } \\
(p<0.001) .\end{array}$ \\
\hline SURPASS-3 (2021) & $\begin{array}{l}\text { Subjects with } \\
\text { T2DM } \\
\text { inadequately } \\
\text { controlled by } \\
\text { metformin with } \\
\text { or without } \\
\text { SGLT2 inhibitors }\end{array}$ & 1947 & $\begin{array}{l}\text { Tirzepatide (one } \\
\text { weekly, 5, 10, or } \\
15 \mathrm{mg} \text { ) versus } \\
\text { titrated insulin } \\
\text { degludec add-on } \\
\text { metformin with } \\
\text { or without } \\
\text { SGLT2 inhibitors }\end{array}$ & $\begin{array}{l}\text { Change from } \\
\text { baseline in } \\
\text { HbA1c at } \\
52 \text { week. }\end{array}$ & $\begin{array}{l}\text { People with } \\
\text { T2DMobtained better } \\
\text { glycemic control with } \\
\text { tirzepatide than insulin } \\
\text { degludec, while losing } \\
\text { rather than gaining } \\
\text { weight. }\end{array}$ \\
\hline
\end{tabular}


Table 1. Cont.

\begin{tabular}{|c|c|c|c|c|c|}
\hline Study & Population & Sample Size & Intervention & $\begin{array}{l}\text { Primary } \\
\text { Outcome }\end{array}$ & Results \\
\hline SURPASS-4 (2021) & $\begin{array}{c}\text { People with } \\
\text { T2DM with } \\
\text { increased CV risk } \\
\text { who are treated } \\
\text { with metformin, } \\
\text { or a sulfonylurea } \\
\text { or an } \\
\text { SGLT-2 inhibitor }\end{array}$ & 2002 & $\begin{array}{l}\text { Tirzepatide } \\
(5 \mathrm{mg}, 10 \mathrm{mg}, \\
\text { and } 15 \mathrm{mg}) \text { with } \\
\text { titrated insulin } \\
\text { glargine }\end{array}$ & $\begin{array}{l}\text { Change from } \\
\text { baseline in } \\
\text { HbA1c (10 mg } \\
\text { and } 15 \mathrm{mg}) \text { at } \\
52 \text { weeks, and to } \\
\text { assess the } \\
\text { efficacy and } \\
\text { safety of } \\
\text { tirzepatide taken } \\
\text { once a week to } \\
\text { insulin glargine } \\
\text { taken once daily } \\
\text { in participants } \\
\text { with T2DMand } \\
\text { increased } \\
\text { cardiovascular } \\
\text { risk. }\end{array}$ & $\begin{array}{l}\text { The highest dose of } \\
\text { tirzepatide led to an } \\
\text { HbA1c reduction of } 2.58 \% \\
\text { and reduced body weight } \\
\text { by }-11.7 \mathrm{~kg} \text { compared } \\
\text { with insulin glargine at } \\
52 \text { weeks. }\end{array}$ \\
\hline SURPASS 5 (2021) & $\begin{array}{l}\text { Patients with } \\
\text { T2DM } \\
\text { inadequately } \\
\text { controlled on } \\
\text { insulin glargine } \\
\text { with or without } \\
\text { metformin }\end{array}$ & 475 & $\begin{array}{l}\text { Tirzepatide } \\
\text { versus placebo in } \\
\text { patients with } \\
\text { T2D } \\
\text { Minadequately } \\
\text { controlled on } \\
\text { insulin glargine } \\
\text { with or without } \\
\text { metformin }\end{array}$ & $\begin{array}{l}\text { To evaluate the } \\
\text { safety and } \\
\text { efficacy of } \\
\text { tirzepatide to } \\
\text { placebo in } \\
\text { participants with } \\
\text { T2DMthat are } \\
\text { already on } \\
\text { insulin glargine, } \\
\text { with or without } \\
\text { metformin, and } \\
\text { change from } \\
\text { baseline in } \\
\text { HbA1c (10 mg } \\
\text { and } 15 \mathrm{mg}) \text { at } \\
40 \text { weeks }\end{array}$ & $\begin{array}{l}\text { Tirzepatide was associated } \\
\text { with greater HbA1c } \\
\text { reductions and body } \\
\text { weight reductions than in } \\
\text { placebo therapy. } \\
\text { Additionally, results } \\
\text { indicated } 97 \% \text { of } \\
\text { participants receiving } \\
\text { tirzepatide achieved an } \\
\text { HbA1c of less than } 7 \% \\
\text { and } 62 \% \text { achieved an } \\
\mathrm{HbA} 1 \mathrm{c} \text { of less than } 5.7 \% \text {. }\end{array}$ \\
\hline $\begin{array}{l}\text { SURPASS-6 } \\
\text { (recruiting) }\end{array}$ & $\begin{array}{c}\text { T2DM } \\
\text { inadequately } \\
\text { controlled on } \\
\text { insulin glargine } \\
\text { (U100) with or } \\
\text { without } \\
\text { metformin }\end{array}$ & 1182 & $\begin{array}{l}\text { Tirzepatide once } \\
\text { weekly versus } \\
\text { insulin lispro } \\
\text { (U100) three } \\
\text { times daily }\end{array}$ & $\begin{array}{l}\text { To compare the } \\
\text { safety and } \\
\text { efficacy of the } \\
\text { tirzepatide to } \\
\text { insulin lispro } \\
\text { (U100) three } \\
\text { times a day in } \\
\text { participants with } \\
\text { T2DM that are } \\
\text { already on } \\
\text { insulin glargine } \\
\text { (U100), with or } \\
\text { without } \\
\text { metformin, } \\
\text { monitoring } \\
\text { change from } \\
\text { baseline in } \\
\text { HbA1c }\end{array}$ & $\begin{array}{c}\text { Estimated study } \\
\text { completion date: } \\
18 \text { November } 2022\end{array}$ \\
\hline
\end{tabular}


Table 1. Cont.

\begin{tabular}{|c|c|c|c|c|c|}
\hline Study & Population & Sample Size & Intervention & $\begin{array}{l}\text { Primary } \\
\text { Outcome }\end{array}$ & Results \\
\hline $\begin{array}{l}\text { SURPASS-CVOT } \\
\text { (Recruiting) }\end{array}$ & $\begin{array}{l}\text { Patients with } \\
\text { T2DM and } \\
\text { increased } \\
\text { cardiovascular } \\
\text { risk }\end{array}$ & 12,500 & $\begin{array}{l}\text { Tirzepatide } \\
(5 \mathrm{mg}, 10 \mathrm{mg}, \\
15 \mathrm{mg}) \text { versus } \\
\text { dulaglutide } \\
(1.5 \mathrm{mg})\end{array}$ & $\begin{array}{l}\text { Time to first } \\
\text { occurrence of } \\
\text { death from } \\
\text { cardiovascular } \\
\text { (CV) causes, } \\
\text { myocardial } \\
\text { infarction (MI), } \\
\text { or stroke } \\
\text { (MACE-3) }\end{array}$ & $\begin{array}{l}\text { Estimated study } \\
\text { completion date: } \\
17 \text { October } 2024\end{array}$ \\
\hline $\begin{array}{l}\text { SURPASS } \\
\text { AP-Combo } \\
\text { (Active, not } \\
\text { recruiting) }\end{array}$ & $\begin{array}{l}\text { Subjects with } \\
\text { T2DM treated } \\
\text { with metformin } \\
\text { with or without a } \\
\text { sulfonylurea }\end{array}$ & 917 & $\begin{array}{l}\text { Tirzepatide } \\
\text { (5 mg, } 10 \mathrm{mg} \text {, } \\
15 \mathrm{mg} \text { ) once } \\
\text { weekly versus } \\
\text { titrated insulin } \\
\text { glargine add-on } \\
\text { metformin with } \\
\text { or without a } \\
\text { sulfonylurea }\end{array}$ & $\begin{array}{l}\text { Mean change } \\
\text { from baseline in } \\
\mathrm{HbA1c}(10 \mathrm{mg} \\
\text { and } 15 \mathrm{mg})\end{array}$ & $\begin{array}{c}\text { Estimated study } \\
\text { completion date: } 26 \\
\text { November } 2021\end{array}$ \\
\hline
\end{tabular}

SURPASS J-mono (NCT03861052) and SURPASS J-combo (NCT03861039) are ongoing clinical trials for the Japanese market; the first is comparing weekly tirzepatide $(5,10$, or $15 \mathrm{mg}$ ) against weekly dulaglutide $0.75 \mathrm{mg}$ in Japanese people taking no other glucoselowering medications during the trial, and the primary endpoint is a change in $\mathrm{HbA} 1 \mathrm{c}$, and the second is a safety study that will monitor adverse events in Japanese people given tirzepatide $(5,10$, or $15 \mathrm{mg})$ in addition to non-incretin-based antidiabetes medications over 52 weeks of treatment.

SURMOUNT-1 trial (NCT04184622, estimated study completion in May 2024) is testing the ability of tirzepatide (at doses of 5,10 , or $15 \mathrm{mg}$ ) to reduce weight in subjects with diabetes and obesity at 72 weeks.

Combination therapies allow for intervention on the multiple mechanisms responsible for hyperglycemia and could reduce residual CV risk in diabetic patients in the future [130-132]. Moreover, due to the increased incidence of T2DM and its poor prognosis, early and intensive treatment is important [133].

\section{Conclusions}

In the last years, scientific research has focused its interest on the synergistic action of GLP-1 and GIP. In vitro and in vivo preclinical studies have demonstrated that co-infusion of GLP-1 and GIP leads to improvement of glucose control and bodyweight regulation, compared with separate administration of each hormone, and these findings have been confirmed in human studies.

Based on promising preclinical data, a dual GIP/GLP-1 receptor agonist, named "twincretin", has been developed and emerging evidence showed that in Phase 3 clinical trials, tirzepatide was able to induce a potent glucose-lowering and weight loss with adverse effects comparable to those of established GLP-1 receptor agonist. The long-term and cardiovascular outcomes of tirzepatide will be investigated in the SURPASS-CVOT.

Furthermore, recent preclinical studies have demonstrated beneficial effects when GLP-1 R was combined with glucagon receptor agonists. Indeed, GLP-1R has been matched with Glucagon receptor agonist in unimolecular agonist (SAR425899, Sanofi, Paris, France) and preclinical studies showed that decreased bodyweight in diet-induced obese mice and decreased glucose levels in $\mathrm{db} / \mathrm{db}$ mice [134]. 
Similarly, another GLP-1R/GR dual agonist (MEDI0382, MedImmune, Gaithersburg, MD, USA), was able to significantly reduce bodyweight and to ameliorate glucose levels when compared with liraglutide, in non-human primates [135].

Based on these evidences, GLP-1R/GIPR/GR triple agonists have been under development and in preclinical studies have shown that the reduction of bodyweight was greater than the same dose of a GLP-1/GIPR dual agonist in diet-induced obese mice [104,136].

Author Contributions: M.C.P., M.P., and I.Z. designed the study, analyzed the results, and wrote the manuscript; R.P., F.G., and S.L. provided technical assistance; F.A., M.A., and A.S. supervised the study, and reviewed and edited the manuscript. All authors have read and agreed to the published version of the manuscript.

Funding: This research received no external funding.

Institutional Review Board Statement: Not applicable.

Informed Consent Statement: Not applicable.

Conflicts of Interest: The authors declare no conflict of interest.

$\begin{array}{ll}\text { Abbreviations } \\ \text { BMI } & \text { Body mass index } \\ \text { CV } & \text { Cardiovascular } \\ \text { cAMP } & \text { Cyclic-adenosine-monophosphate } \\ \text { CVOT } & \text { Cardiovascular outcome trial } \\ \text { DPP-4 } & \text { Dipeptidyl peptidase } 4 \\ \text { FDA } & \text { United States Food and Drug Administration } \\ \text { FFA } & \text { Free fatty acids } \\ \text { GIP } & \text { Glucose-dependent insulinotropic polypeptide } \\ \text { GIPRs } & \text { GIP receptors } \\ \text { GLP-1 } & \text { Glucagon-like peptide-1 } \\ \text { GLP-1 R } & \text { Glucagon-like peptide-1 receptor } \\ \text { GLP-1 RA } & \text { Glucagon-like peptide-1 receptor agonists } \\ \text { GR } & \text { Glucagon receptor } \\ \text { HbA1c } & \text { Glycated hemoglobin A1c } \\ \text { i.v. } & \text { Intravenous } \\ \text { MACE } & \text { Major cardiovascular events } \\ \text { MI } & \text { Myocardial infarction } \\ \text { OGTT } & \text { Oral glucose tolerance test } \\ \text { PEG } & \text { Polyethylene glycol } \\ \text { SGLT } & \text { Sodium-glucose co-transporter type } \\ \text { SD } & \text { Standard deviation } \\ \text { T2DM } & \text { Type 2 diabetes mellitus }\end{array}$

\section{References}

1. Zunz, E.; La Barre, J. Contributions A L'Étude des Variations Physiologiques De La Sécrétion Interne Du Pancréas. Arch. Int. Phys. 1929, 31, 162-179. (In French) [CrossRef]

2. Bayliss, W.M.; Starling, E.H. The mechanism of pancreatic secretion. J. Physiol. 1902, 28, 325-353. [CrossRef]

3. Moore, B. On the treatment of Diabetus mellitus by acid extract of Duodenal Mucous Membrane. Biochem. J. 1906, 1, 28-38. [CrossRef] [PubMed]

4. Mcintyre, N.; Holdsworth, C.D.; Turner, D.S. New interpretation of oral glucose tolerance. Lancet 1964, 2, 20-21. [CrossRef]

5. Unger, R.H.; Eisentraut, A.M. Entero-insularaxis. Arch. Intern. Med. 1969, 123, 261-266. [CrossRef]

6. $\quad$ Eissele, R.; Göke, R.; Willemer, S.; Harthus, H.P.; Vermeer, H.; Arnold, R.; Göke, B. Glucagon-like peptide-1 cells in the gastrointestinal tract and pancreas of rat, pig and man. Eur. J. Clin. Investig. 1992, 22, 283-291. [CrossRef]

7. Diakogiannaki, E.; Gribble, F.M.; Reimann, F. Nutrient detection by incretin hormone secreting cells. Physiol. Behav. 2012, 106, 387-393. [CrossRef]

8. Takeda, J.; Seino, Y.; Tanaka, K.; Fukumoto, H.; Kayano, T.; Takahashi, H.; Mitani, T.; Kurono, M.; Suzuki, T.; Tobe, T. Sequence of an intestinal cDNA encoding human gastric inhibitory polypeptide precursor. Proc. Natl. Acad. Sci. USA 1987, 84, 7005-7008. [CrossRef] 
9. Brown, J.C.; Mutt, V.; Pederson, R.A. Further purification of a polypeptide demonstrating enterogastrone activity. J. Physiol. 1970, 209, 57-64. [CrossRef]

10. Baggio, L.L.; Drucker, D.J. Biology of incretins: GLP-1 and GIP. Gastroenterology 2007, 132, 2131-2157. [CrossRef]

11. Nauck, M.A.; Meier, J.J. The incretin effect in healthy individuals and those with type 2 diabetes: Physiology, pathophysiology, and response to therapeutic interventions. Lancet. Diabetes Endocrinol. 2016, 4, 525-536. [CrossRef]

12. Drucker, D.J.; Nauck, M.A. The incretin system: Glucagon-like peptide-1 receptor agonists and dipeptidyl peptidase-4 inhibitors in type 2 diabetes. Lancet 2006, 368, 1696-1705. [CrossRef]

13. Caruso, I.; Cignarelli, A.; Giorgino, F. Heterogeneity and Similarities in GLP-1 Receptor Agonist Cardiovascular Outcomes Trials Trends Endocrinol. Metab. TEM 2019, 30, 578-589. [CrossRef]

14. Ma, X.; Liu, Z.; Ilyas, I.; Little, P.J.; Kamato, D.; Sahebka, A.; Chen, Z.; Luo, S.; Zheng, X.; Weng, J.; et al. GLP-1 receptor agonists (GLP-1RAs): Cardiovascular actions and therapeutic potential. Int. J. Biol. Sci. 2021, 17, 2050-2068. [CrossRef] [PubMed]

15. Chia, C.W.; Carlson, O.D.; Kim, W.; Shin, Y.K.; Charles, C.P.; Kim, H.S.; Melvin, D.L.; Egan, J.M. Exogenous glucose-dependent insulinotropic polypeptide worsens post prandial hyperglycemia in type 2 diabetes. Diabetes 2009, 58, 1342-1349. [CrossRef] [PubMed]

16. Højberg, P.V.; Vilsbøll, T.; Rabøl, R.; Knop, F.K.; Bache, M.; Krarup, T.; Holst, J.J.; Madsbad, S. Four weeks of near-normalisation of blood glucose improves the insulin response to glucagon-like peptide-1 and glucose-dependent insulinotropic polypeptide in patients with type 2 diabetes. Diabetologia 2009, 52, 199-207. [CrossRef]

17. Bokvist, K.; Brown, R.; Coskun, T.; Cox, A.; Cummins, R.; Farb, T.; Ficorilli, J.; Lewis, A.P.; Marcelo, M.; O’Farrell, L.; et al LY3298176, a novel long-actingGIP/GLP-1 coagonist, shows enhanced activity on weight loss and energy utilization whilst maintaining its efficacy for glycaemic control. Diabetologia 2017, 60 (Suppl. 1), S399.

18. Frias, J.P.; Bastyr, E.J., III; Vignati, L.; Tschöp, M.H.; Schmitt, C.; Owen, K.; Christensen, R.H.; DiMarchi, R.D. The Sustained Effects of a Dual GIP/GLP-1 Receptor Agonist, NNC0090-2746, in Patients with Type 2 Diabetes. Cell Metab. 2017, 26, 343-352.e2. [CrossRef] [PubMed]

19. Frias, J.P.; Nauck, M.A.; Van, J.; Kutner, M.E.; Cui, X.; Benson, C.; Urva, S.; Gimeno, R.E.; Milicevic, Z.; Robins, D.; et al Efficacy and safety of LY3298176, a novel dual GIP and GLP-1 receptor agonist, in patients with type 2 diabetes: A randomised, placebo-controlled and active comparator-controlled phase 2 trial. Lancet 2018, 392, 2180-2193. [CrossRef]

20. Boer, G.A.; Holst, J.J. Incretin Hormones and Type 2 Diabetes-Mechanistic Insights and Therapeutic Approaches. Biology 2020, 9 , 473. [CrossRef] [PubMed]

21. Sacks, D.; Baxter, B.; Campbell, B.; Carpenter, J.S.; Cognard, C.; Dippel, D.; Eesa, M.; Fischer, U.; Hausegger, K.; Hirsch, J.A.; et al. Multisociety Consensus Quality Improvement Revised Consensus Statement for Endovascular Therapy of Acute Ischemic Stroke. J. Vasc. Interv. Radiol. JVIR 2018, 29, 441-453. [CrossRef] [PubMed]

22. Elrick, H.; Stimmler, L.; Hlad, C.J.; Arai, Y., Jr. Plasma insulin response to oral and intravenous glucose administration. J. Clin. Endocrinol. Metab. 1964, 24, 1076-1082. [CrossRef]

23. McIntyre, N.; Holdsworth, C.D.; Turner, D.S. Intestinal factors in the control of insulin secretion. J. Clin. Endocrinol. Metab. 1965, 25, 1317-1324. [CrossRef]

24. Fujita, Y.; Wideman, R.D.; Asadi, A.; Yang, G.K.; Baker, R.; Webber, T.; Zhang, T.; Wang, R.; Ao, Z.; Warnock, G.L.; et al. Glucosedependent insulinotropic polypeptide is expressed in pancreatic islet alpha-cells and promotes insulin secretion. Gastroenterology 2010, 138, 1966-1975. [CrossRef]

25. Brown, J.C. Gastric inhibitory polypeptide. In Monographs on Endocrinology; Springer Science \& Business Media: Berlin/Heidelberg Germany, 1982; Volume 24, 88p.

26. Gupta, K.; Raja, A. Physiology, Gastric Inhibitory Peptide; StatPearls Publishing: Treasure Island, FL, USA, 2021.

27. Fehmann, H.C.; Göke, R.; Göke, B. Cell and molecular biology of the incretin hormones glucagon-like peptide-I and glucosedependent insulin releasing polypeptide. Endocr. Rev. 1995, 16, 390-410. [CrossRef]

28. Kuhre, R.E.; Wewer Albrechtsen, N.J.; Hartmann, B.; Deacon, C.F.; Holst, J.J. Measurement of the incretin hormones: Glucagon-like peptide-1 and glucose-dependent insulinotropic peptide. J. Diabetes Complicat. 2015, 29, 445-450. [CrossRef]

29. Mayo, K.E.; Miller, L.J.; Bataille, D.; Dalle, S.; Göke, B.; Thorens, B.; Drucker, D.J. International Union of Pharmacology. XXXV. The glucagon receptor family. Pharmacol. Rev. 2003, 55, 167-194. [CrossRef] [PubMed]

30. Thornberry, N.A.; Gallwitz, B. Mechanism of action of inhibitors of dipeptidyl-peptidase-4 (DPP-4). Best Pract. Research. Clin. Endocrinol. Metab. 2009, 23, 479-486. [CrossRef]

31. Usdin, T.B.; Mezey, E.; Button, D.C.; Brownstein, M.J.; Bonner, T.I. Gastric inhibitory polypeptide receptor, a member of the secretin-vasoactive intestinal peptide receptor family, is widely distributed in peripheral organs and the brain. Endocrinology $\mathbf{1 9 9 3}$ 133, 2861-2870. [CrossRef]

32. Ding, W.G.; Gromada, J. Protein kinase A-dependent stimulation of exocytosis in mouse pancreatic beta-cells by glucosedependent insulinotropic polypeptide. Diabetes 1997, 46, 615-621. [CrossRef] [PubMed]

33. Gromada, J.; Bokvist, K.; Ding, W.G.; Holst, J.J.; Nielsen, J.H.; Rorsman, P. Glucagon-like peptide 1 (7-36) amide stimulates exocytosis in human pancreatic beta-cells by both proximal and distal regulatory steps in stimulus-secretion coupling. Diabetes 1998, 47, 57-65. [CrossRef] [PubMed]

34. Wang, Y.; Montrose-Rafizadeh, C.; Adams, L.; Raygada, M.; Nadiv, O.; Egan, J.M. GIP regulates glucose transporters, hexokinases, and glucose-induced insulin secretion in RIN 1046-38 cells. Mol. Cell. Endocrinol. 1996, 116, 81-87. [CrossRef] 
35. Nyberg, J.; Anderson, M.F.; Meister, B.; Alborn, A.M.; Ström, A.K.; Brederlau, A.; Illerskog, A.C.; Nilsson, O.; Kieffer, T.J.; Hietala, M.A.; et al. Glucose-dependent insulinotropic polypeptide is expressed in adult hippocampus and induces progenitor cell proliferation. J. Neurosci. Off. J. Soc. Neurosci. 2005, 25, 1816-1825. [CrossRef]

36. Irwin, N.; Gault, V.; Flatt, P.R. Therapeutic potential of the original incretin hormone glucose-dependent insulinotropic polypeptide: Diabetes, obesity, osteoporosis and Alzheimer's disease? Expert Opin. Investig. Drugs 2010, 19, 1039-1048. [CrossRef]

37. Villar, H.V.; Fender, H.R.; Rayford, P.L.; Bloom, S.R.; Ramus, N.I.; Thompson, J.C. Suppression of gastrin release and gastric secretion by gastric inhibitory polypeptide (GIP) and vasoactive intestinal polypeptide (VIP). Ann. Surg. 1976, 184, 97-102. [CrossRef]

38. Nauck, M.A.; Bartels, E.; Orskov, C.; Ebert, R.; Creutzfeldt, W. Lack of effect of synthetic human gastric inhibitory polypeptide and glucagon-like peptide 1 [7-36 amide] infused at near-physiological concentrations on pentagastrin-stimulated gastric acid secretion in normal human subjects. Digestion 1992, 52, 214-221. [CrossRef]

39. Besterman, H.S.; Cook, G.C.; Sarson, D.L.; Christofides, N.D.; Bryant, M.G.; Gregor, M.; Bloom, S.R. Gut hormones in tropical malabsorption. Br. Med. J. 1979, 2, 1252-1255. [CrossRef]

40. Besterman, H.S.; Bloom, S.R.; Sarson, D.L.; Blackburn, A.M.; Johnston, D.I.; Patel, H.R.; Stewart, J.S.; Modigliani, R.; Guerin, S.; Mallinson, C.N. Gut-hormone profile in coeliac disease. Lancet 1978, 1, 785-788. [CrossRef]

41. Inagaki, N.; Seino, Y.; Takeda, J.; Yano, H.; Yamada, Y.; Bell, G.I.; Eddy, R.L.; Fukushima, Y.; Byers, M.G.; Shows, T.B. Gastric inhibitory polypeptide: Structure and chromosomal localization of the human gene. Mol. Endocrinol. 1989, 3, $1014-1021$. [CrossRef]

42. Vollmer, K.; Holst, J.J.; Baller, B.; Ellrichmann, M.; Nauck, M.A.; Schmidt, W.E.; Meier, J.J. Predictors of incretin concentrations in subjects with normal, impaired, and diabetic glucose tolerance. Diabetes 2008, 57, 678-687. [CrossRef]

43. Nauck, M.A.; Quast, D.R.; Wefers, J.; Pfeiffer, A. The evolving story of incretins (GIP and GLP-1) in metabolic and cardiovascular disease: A pathophysiological update. Diabetes Obes. Metab. 2021, 23 (Suppl. 3), 5-29. [CrossRef]

44. Seino, Y.; Fukushima, M.; Yabe, D. GIP and GLP-1, the two incretin hormones: Similarities and differences. J. Diabetes Investig. 2010, 1, 8-23. [CrossRef] [PubMed]

45. Mentlein, R. Dipeptidyl-peptidase IV (CD26)-role in the inactivation of regulatory peptides. Regul. Pept. 1999, 85, 9-24. [CrossRef]

46. Nauck, M.A.; Siemsglüss, J.; Orskov, C.; Holst, J.J. Release of glucagon-like peptide 1 (GLP-1 [7-36 amide]), gastric inhibitory polypeptide (GIP) and insulin in response to oral glucose after upper and lower intestinal resections. Z. Fur Gastroenterol. 1996, 34, 159-166.

47. Hansen, L.; Deacon, C.F.; Orskov, C.; Holst, J.J. Glucagon-like peptide-1-(7-36) amide is transformed to glucagon-like peptide-1(9-36)amide by dipeptidyl peptidase IV in the capillaries supplying the L cells of the porcine intestine. Endocrinology 1999, 140, 5356-5363. [CrossRef]

48. Thorens, B.; Porret, A.; Bühler, L.; Deng, S.P.; Morel, P.; Widmann, C. Cloning and functional expression of the human islet GLP-1 receptor. Demonstration that exendin-4 is an agonist and exendin-(9-39) an antagonist of the receptor. Diabetes 1993, 42, 1678-1682. [CrossRef] [PubMed]

49. Thorens, B. Expression cloning of the pancreatic beta cell receptor for the gluco-incretin hormone glucagon-like peptide 1. Proc. Natl. Acad. Sci. USA 1992, 89, 8641-8645. [CrossRef] [PubMed]

50. Moens, K.; Heimberg, H.; Flamez, D.; Huypens, P.; Quartier, E.; Ling, Z.; Pipeleers, D.; Gremlich, S.; Thorens, B.; Schuit, F. Expression and functional activity of glucagon, glucagon-like peptide I, and glucose-dependent insulinotropic peptide receptors in rat pancreatic islet cells. Diabetes 1996, 45, 257-261. [CrossRef]

51. Amiranoff, B.; Couvineau, A.; Vauclin-Jacques, N.; Laburthe, M. Gastric inhibitory polypeptide receptor in hamster pancreatic beta cells. Direct cross-linking, solubilization and characterization as a glycoprotein. Eur. J. Biochem. 1986, 159, 353-358. [CrossRef]

52. Gremlich, S.; Porret, A.; Hani, E.H.; Cherif, D.; Vionnet, N.; Froguel, P.; Thorens, B. Cloning, functional expression, and chromosomal localization of the human pancreatic islet glucose-dependent insulinotropic polypeptide receptor. Diabetes 1995, 44, 1202-1208. [CrossRef]

53. Volz, A.; Göke, R.; Lankat-Buttgereit, B.; Fehmann, H.C.; Bode, H.P.; Göke, B. Molecular cloning, functional expression, and signal transduction of the GIP-receptor cloned from a human insulinoma. FEBS Lett. 1995, 373, 23-29. [CrossRef]

54. Wheeler, M.B.; Gelling, R.W.; McIntosh, C.H.; Georgiou, J.; Brown, J.C.; Pederson, R.A. Functional expression of the rat pancreatic islet glucose-dependent insulinotropic polypeptide receptor: Ligand binding and intracellular signaling properties. Endocrinology 1995, 136, 4629-4639. [CrossRef] [PubMed]

55. Yamada, Y.; Hayami, T.; Nakamura, K.; Kaisaki, P.J.; Someya, Y.; Wang, C.Z.; Seino, S.; Seino, Y. Human gastric inhibitory polypeptide receptor: Cloning of the gene (GIPR) and cDNA. Genomics 1995, 29, 773-776. [CrossRef]

56. Yasuda, K.; Inagaki, N.; Yamada, Y.; Kubota, A.; Seino, S.; Seino, Y. Hamster gastric inhibitory polypeptide receptor expressed in pancreatic islets and clonal insulin-secreting cells: Its structure and functional properties. Biochem. Biophys. Res. Commun. 1994, 205, 1556-1562. [CrossRef]

57. Dillon, J.S.; Tanizawa, Y.; Wheeler, M.B.; Leng, X.H.; Ligon, B.B.; Rabin, D.U.; Yoo-Warren, H.; Permutt, M.A.; Boyd, A.E., III. Cloning and functional expression of the human glucagon-like peptide-1 (GLP-1) receptor. Endocrinology 1993, 133, 1907-1910. [CrossRef] 
58. Stoffel, M.; Espinosa, R.; Le Beau, M.M., III; Bell, G.I. Human glucagon-like peptide-1 receptor gene. Localization to chromosome band 6 p21 by fluorescence in situ hybridization and linkage of a highly polymorphic simple tandem repeat DNA polymorphism to other markers on chromosome 6. Diabetes 1993, 42, 1215-1218. [CrossRef]

59. Perley, M.J.; Kipnis, D.M. Plasma insulin responses to oral and intravenous glucose: Studies in normal and diabetic sujbjects. $J$. Clin. Investig. 1967, 46, 1954-1962. [CrossRef] [PubMed]

60. Gabe, M.; Sparre-Ulrich, A.H.; Pedersen, M.F.; Gasbjerg, L.S.; Inoue, A.; Bräuner-Osborne, H.; Hartmann, B.; Rosenkilde, M.M. Human GIP(3-30) $\mathrm{NH}_{2}$ inhibits G protein-dependent as well as G protein-independent signaling and is selective for the GIP receptor with high-affinity binding to primate but not rodent GIP receptors. Biochem. Pharmacol. 2018, 150, 97-107. [CrossRef] [PubMed]

61. Mohammad, S.; Patel, R.T.; Bruno, J.; Panhwar, M.S.; Wen, J.; McGraw, T.E. A naturally occurring GIP receptor variant undergoes enhanced agonist-induced desensitization, which impairs GIP control of adipose insulin sensitivity. Mol. Cell. Biol. 2014, 34, 3618-3629. [CrossRef] [PubMed]

62. Maida, A.; Hansotia, T.; Longuet, C.; Seino, Y.; Drucker, D.J. Differential importance of glucose-dependent insulinotropic polypeptide vs. glucagon-like peptide 1 receptor signaling for beta cell survival in mice. Gastroenterology 2009, 137, $2146-2157$. [CrossRef]

63. Orskov, C.; Holst, J.J.; Nielsen, O.V. Effect of truncated glucagon-like peptide-1 [proglucagon-(78-107) amide] on endocrine secretion from pig pancreas, antrum, and nonantral stomach. Endocrinology 1988, 123, 2009-2013. [CrossRef]

64. Nauck, M.A.; Heimesaat, M.M.; Orskov, C.; Holst, J.J.; Ebert, R.; Creutzfeldt, W. Preserved incretin activity of glucagon-like peptide 1 [7-36 amide] but not of synthetic human gastric inhibitory polypeptide in patients with type-2 diabetes mellitus. J. Clin. Investig. 1993, 91, 301-307. [CrossRef] [PubMed]

65. Nauck, M.A.; Kleine, N.; Orskov, C.; Holst, J.J.; Willms, B.; Creutzfeldt, W. Normalization of fasting hyperglycaemia by exogenous glucagon-like peptide 1 (7-36 amide) in type 2 (non-insulin-dependent) diabetic patients. Diabetologia 1993, 36, 741-744. [CrossRef] [PubMed]

66. Nauck, M.A.; Heimesaat, M.M.; Behle, K.; Holst, J.J.; Nauck, M.S.; Ritzel, R.; Hüfner, M.; Schmiegel, W.H. Effects of glucagon-like peptide 1 on counterregulatory hormone responses, cognitive functions, and insulin secretion during hyperinsulinemic, stepped hypoglycemic clamp experiments in healthy volunteers. J. Clin. Endocrinol. Metab. 2002, 87, 1239-1246. [CrossRef] [PubMed]

67. Pederson, R.A.; Brown, J.C. Interaction of gastric inhibitory polypeptide, glucose, and arginine on insulin and glucagon secretion from the perfused rat pancreas. Endocrinology 1978, 103, 610-615. [CrossRef] [PubMed]

68. Christensen, M.B.; Calanna, S.; Holst, J.J.; Vilsbøll, T.; Knop, F.K. Glucose-dependent insulinotropic polypeptide: Blood glucose stabilizing effects in patients with type 2 diabetes. J. Clin. Endocrinol. Metab. 2014, 99, E418-E426. [CrossRef] [PubMed]

69. Carr, R.D.; Larsen, M.O.; Winzell, M.S.; Jelic, K.; Lindgren, O.; Deacon, C.F.; Ahrén, B. Incretin and islet hormonal responses to fat and protein ingestion in healthy men. Am. J. Physiology. Endocrinol. Metab. 2008, 295, E779-E784. [CrossRef] [PubMed]

70. Thomsen, C.; Rasmussen, O.; Lousen, T.; Holst, J.J.; Fenselau, S.; Schrezenmeir, J.; Hermansen, K. Differential effects of saturated and monounsaturated fatty acids on postprandial lipemia and incretin responses in healthy subjects. Am. J. Clin. Nutr. 1999, 69, 1135-1143. [CrossRef]

71. Creutzfeldt, W.; Ebert, R.; Willms, B.; Frerichs, H.; Brown, J.C. Gastric inhibitory polypeptide (GIP) and insulin in obesity: Increased response to stimulation and defective feedback control of serum levels. Diabetologia 1978, 14, 15-24. [CrossRef] [PubMed]

72. Salera, M.; Giacomoni, P.; Pironi, L.; Cornia, G.; Capelli, M.; Marini, A.; Benfenati, F.; Miglioli, M.; Barbara, L. Gastric inhibitory polypeptide release after oral glucose: Relationship to glucose intolerance, diabetes mellitus, and obesity. J. Clin. Endocrinol. Metab. 1982, 55, 329-336. [CrossRef]

73. Musso, G.; Gambino, R.; Pacini, G.; De Michieli, F.; Cassader, M. Prolonged saturated fat-induced, glucose-dependent insulinotropic polypeptide elevation is associated with adipokine imbalance and liver injury in nonalcoholic steatohepatitis: Dysregulated enteroadipocyte axis as a novel feature of fatty liver. Am. J. Clin. Nutr. 2009, 89, 558-567. [CrossRef]

74. Asmar, M.; Simonsen, L.; Madsbad, S.; Stallknecht, B.; Holst, J.J.; Bülow, J. Glucose-dependent insulinotropic polypeptide may enhance fatty acid re-esterification in subcutaneous abdominal adipose tissue in lean humans. Diabetes 2010, 59, 2160-2163. [CrossRef]

75. Ebert, R.; Nauck, M.; Creutzfeldt, W. Effect of exogenous or endogenous gastric inhibitory polypeptide (GIP) on plasma triglyceride responses in rats. Horm. Metab. Res. 1991, 23, 517-521. [CrossRef]

76. Wasada, T.; McCorkle, K.; Harris, V.; Kawai, K.; Howard, B.; Unger, R.H. Effect of gastric inhibitory polypeptide on plasma levels of chylomicron triglycerides in dogs. J. Clin. Investig. 1981, 68, 1106-1107. [CrossRef]

77. Beck, B.; Max, J.P. Gastric inhibitory polypeptide enhancement of the insulin effect on fatty acid incorporation into adipose tissue in the rat. Regul. Pept. 1983, 7, 3-8. [CrossRef]

78. McLean, B.A.; Wong, C.K.; Campbell, J.E.; Hodson, D.J.; Trapp, S.; Drucker, D.J. Revisiting the Complexity of GLP-1 Action from Sites of Synthesis to Receptor Activation. Endocr. Rev. 2021, 42, 101-132. [CrossRef]

79. Baggio, L.L.; Yusta, B.; Mulvihill, E.E.; Cao, X.; Streutker, C.J.; Butany, J.; Cappola, T.P.; Margulies, K.B.; Drucker, D.J. GLP1 Receptor Expression Within the Human Heart. Endocrinology 2018, 159, 1570-1584. [CrossRef]

80. Heimbürger, S.M.; Bergmann, N.C.; Augustin, R.; Gasbjerg, L.S.; Christensen, M.B.; Knop, F.K. Glucose-dependent insulinotropic polypeptide (GIP) and cardiovascular disease. Peptides 2020, 125, 170174. [CrossRef] 
81. Heppner, K.M.; Kirigiti, M.; Secher, A.; Paulsen, S.J.; Buckingham, R.; Pyke, C.; Knudsen, L.B.; Vrang, N.; Grove, K.L. Expression and distribution of glucagon-like peptide-1 receptor mRNA, protein and binding in the male nonhuman primate (Macaca mulatta) brain. Endocrinology 2015, 156, 255-267. [CrossRef]

82. Paratore, S.; Ciotti, M.T.; Basille, M.; Vaudry, D.; Gentile, A.; Parenti, R.; Calissano, P.; Cavallaro, S. Gastric inhibitory polypeptide and its receptor are expressed in the central nervous system and support neuronal survival. Cent. Nerv. Syst. Agents Med. Chem. 2011, 11, 210-222. [CrossRef]

83. Wettergren, A.; Schjoldager, B.; Mortensen, P.E.; Myhre, J.; Christiansen, J.; Holst, J.J. Truncated GLP-1 (proglucagon 78-107-amide) inhibits gastric and pancreatic functions in man. Dig. Dis. Sci. 1993, 38, 665-673. [CrossRef] [PubMed]

84. Nauck, M.A.; Niedereichholz, U.; Ettler, R.; Holst, J.J.; Orskov, C.; Ritzel, R.; Schmiegel, W.H. Glucagon-like peptide 1 inhibition of gastric emptying outweighs its insulinotropic effects in healthy humans. Am. J. Physiol. 1997, 273, E981-E988. [CrossRef]

85. Willms, B.; Werner, J.; Holst, J.J.; Orskov, C.; Creutzfeldt, W.; Nauck, M.A. Gastric emptying, glucose responses, and insulin secretion after a liquid test meal: Effects of exogenous glucagon-like peptide-1 (GLP-1)-(7-36) amide in type 2 (noninsulindependent) diabetic patients. J. Clin. Endocrinol. Metab. 1996, 81, 327-332. [CrossRef]

86. Meier, J.J.; Goetze, O.; Anstipp, J.; Hagemann, D.; Holst, J.J.; Schmidt, W.E.; Gallwitz, B.; Nauck, M.A. Gastric inhibitory polypeptide does not inhibit gastric emptying in humans. Am. J. Physiol. Endocrinol. Metab. 2004, 286, E621-E625. [CrossRef]

87. Holst, J.J.; Windeløv, J.A.; Boer, G.A.; Pedersen, J.; Svendsen, B.; Christensen, M.; Torekov, S.; Asmar, M.; Hartmann, B.; Nissen, A. Searching for the physiological role of glucose-dependent insulinotropic polypeptide. J. Diabetes Investig. 2016, 7, 8-12. [CrossRef]

88. Samms, R.J.; Coghlan, M.P.; Sloop, K.W. How May GIP Enhance the Therapeutic Efficacy of GLP-1? Trends Inendocrinol. Metab. TEM 2020, 31, 410-421. [CrossRef] [PubMed]

89. Elahi, D.; McAloon-Dyke, M.; Fukagawa, N.K.; Meneilly, G.S.; Sclater, A.L.; Minaker, K.L.; Habener, J.F.; Andersen, D.K. The insulinotropic actions of glucose-dependent insulinotropic polypeptide (GIP) and glucagon-like peptide-1 (7-37) in normal and diabetic subjects. Regul. Pept. 1994, 51, 63-74. [CrossRef]

90. Finan, B.; Ma, T.; Ottaway, N.; Müller, T.D.; Habegger, K.M.; Heppner, K.M.; Kirchner, H.; Holland, J.; Hembree, J.; Raver, C.; et al. Unimolecular dual incretins maximize metabolic benefits in rodents, monkeys, and humans. Sci. Transl. Med. 2013, 5, 209 ra151. [CrossRef]

91. Nauck, M.A.; Bartels, E.; Orskov, C.; Ebert, R.; Creutzfeldt, W. Additive insulinotropic effects of exogenous synthetic human gastric inhibitory polypeptide and glucagon-like peptide-1-(7-36) amide infused at near-physiological insulinotropic hormone and glucose concentrations. J. Clin. Endocrinol. Metab. 1993, 76, 912-917. [CrossRef] [PubMed]

92. Skow, M.A.; Bergmann, N.C.; Knop, F.K. Diabetes and obesity treatment based on dual incretin receptor activation: 'twincretins'. Diabetes Obes. Metab. 2016, 18, 847-854. [CrossRef] [PubMed]

93. Gallwitz, B.; Witt, M.; Fölsch, U.R.; Creutzfeldt, W.; Schmidt, W.E. Binding specificity and signal transduction of receptors for glucagon-like peptide-1(7-36)amide and gastric inhibitory polypeptide on RINm5F insulinoma cells. J. Mol. Endocrinol. 1993, 10, 259-268. [CrossRef]

94. Delmeire, D.; Flamez, D.; Moens, K.; Hinke, S.A.; Van Schravendijk, C.; Pipeleers, D.; Schuit, F. Prior in vitro exposure to GLP-1 with or without GIP can influence the subsequent beta cell responsiveness. Biochem. Pharmacol. 2004, 68, 33-39. [CrossRef]

95. Lupi, R.; Del Guerra, S.; D'Aleo, V.; Boggi, U.; Filipponi, F.; Marchetti, P. The direct effects of GLP-1 and GIP, alone or in combination, on human pancreatic islets. Regul. Pept. 2010, 165, 129-132. [CrossRef]

96. Gurevich, V.V.; Gurevich, E.V. GPCR monomers and oligomers: It takes all kinds. Trends Neurosci. 2008, 31, 74-81. [CrossRef] [PubMed]

97. Harikumar, K.G.; Wootten, D.; Pinon, D.I.; Koole, C.; Ball, A.M.; Furness, S.G.; Graham, B.; Dong, M.; Christopoulos, A.; Miller L.J.; et al. Glucagon-like peptide-1 receptor dimerization differentially regulates agonist signaling but does not affect small molecule allostery. Proc. Natl. Acad. Sci. USA 2012, 109, 18607-18612. [CrossRef] [PubMed]

98. Whitaker, G.M.; Lynn, F.C.; McIntosh, C.H.; Accili, E.A. Regulation of GIP and GLP1 receptor cell surface expression by N-glycosylation and receptor heteromerization. PLoS ONE 2012, 7, e32675. [CrossRef] [PubMed]

99. Schelshorn, D.; Joly, F.; Mutel, S.; Hampe, C.; Breton, B.; Mutel, V.; Lütjens, R. Lateral allosterism in the glucagon receptor family: Glucagon-like peptide 1 induces G-protein-coupled receptor heteromer formation. Mol. Pharmacol. 2012, 81, 309-318. [CrossRef]

100. Roed, S.N.; Nøhr, A.C.; Wismann, P.; Iversen, H.; Bräuner-Osborne, H.; Knudsen, S.M.; Waldhoer, M. Functional consequences of glucagon-like peptide-1 receptor cross-talk and trafficking. J. Biol. Chem. 2015, 290, 1233-1243. [CrossRef]

101. Gault, V.A.; Kerr, B.D.; Harriott, P.; Flatt, P.R. Administration of an acylated GLP-1 and GIP preparation provides added beneficial glucose-lowering and insulinotropic actions over single incretins in mice with Type2 diabetes and obesity. Clin. Sci. 2011, 121, 107-117. [CrossRef]

102. Finan, B.; Müller, T.D.; Clemmensen, C.; Perez-Tilve, D.; DiMarchi, R.D.; Tschöp, M.H. Reappraisal of GIP Pharmacology for Metabolic Diseases. Trends Mol. Med. 2016, 22, 359-376. [CrossRef]

103. Finan, B.; Yang, B.; Ottaway, N.; Smiley, D.L.; Ma, T.; Clemmensen, C.; Chabenne, J.; Zhang, L.; Habegger, K.M.; Fischer, K.; et al. A rationally designed monomeric peptide triagonist corrects obesity and diabetes in rodents. Nat. Med. 2015, 21, 27-36. [CrossRef]

104. Nørregaard, P.K.; Deryabina, M.A.; Tofteng Shelton, P.; Fog, J.U.; Daugaard, J.R.; Eriksson, P.O.; Larsen, L.F.; Jessen, L. A novel GIP analogue, ZP4165, enhances glucagon-like peptide-1-induced body weight loss and improves glycaemic control in rodents. Diabetes Obes. Metab. 2018, 20, 60-68. [CrossRef] 
105. Pathak, N.M.; Pathak, V.; Gault, V.A.; McClean, S.; Irwin, N.; Flatt, P.R. Novel dual incretin agonist peptide with antidiabetic and neuroprotective potential. Biochem. Pharmacol. 2018, 155, 264-274. [CrossRef] [PubMed]

106. Tschöp, M.H.; Finan, B.; Clemmensen, C.; Gelfanov, V.; Perez-Tilve, D.; Müller, T.D.; DiMarchi, R.D. Unimolecular Polypharmacy for Treatment of Diabetes and Obesity. Cell Metab. 2016, 24, 51-62. [CrossRef] [PubMed]

107. Bergmann, N.C.; Lund, A.; Gasbjerg, L.S.; Meessen, E.; Andersen, M.M.; Bergmann, S.; Hartmann, B.; Holst, J.J.; Jessen, L.; Christensen, M.B.; et al. Effects of combined GIP and GLP-1 infusion on energy intake, appetite and energy expenditure in overweight/obese individuals: A randomised, crossover study. Diabetologia 2019, 62, 665-675. [CrossRef] [PubMed]

108. Irwin, N.; Hunter, K.; Frizzell, N.; Flatt, P.R. Antidiabetic effects of sub-chronic activation of the GIP receptor alone and in combination with background exendin-4 therapy in high fat fed mice. Regul. Pept. 2009, 153, 70-76. [CrossRef]

109. Irwin, N.; McClean, P.L.; Cassidy, R.S.; O'harte, F.P.; Green, B.D.; Gault, V.A.; Harriott, P.; Flatt, P.R. Comparison of the antidiabetic effects of GIP- and GLP-1-receptor activation in obese diabetic (ob/ob) mice: Studies with DPP IV resistant N-AcGIP and exendin(1-39)amide. DiabetesMetab. Res. Rev. 2007, 23, 572-579. [CrossRef] [PubMed]

110. Young, A.A.; Gedulin, B.R.; Bhavsar, S.; Bodkin, N.; Jodka, C.; Hansen, B.; Denaro, M. Glucose-lowering and insulin-sensitizing actions of exendin-4: Studies in obese diabetic (ob/ob, db/db) mice, diabetic fatty Zucker rats, and diabetic rhesus monkeys (Macaca mulatta). Diabetes 1999, 48, 1026-1034. [CrossRef]

111. Greig, N.H.; Holloway, H.W.; De Ore, K.A.; Jani, D.; Wang, Y.; Zhou, J.; Garant, M.J.; Egan, J.M. Once daily injection of exendin-4 to diabetic mice achieves long-term beneficial effects on blood glucose concentrations. Diabetologia 1999, 42, 45-50. [CrossRef]

112. Killion, E.A.; Wang, J.; Yie, J.; Shi, S.D.; Bates, D.; Min, X.; Komorowski, R.; Hager, T.; Deng, L.; Atangan, L.; et al. Anti-obesity effects of GIPR antagonists alone and in combination with GLP-1R agonists in preclinical models. Sci. Transl. Med. 2018, 10, eaat3392. [CrossRef]

113. Irwin, N.; McClean, P.L.; Flatt, P.R. Comparison of the subchronic antidiabetic effects of DPP IV-resistant GIP and GLP-1 analogues in obese diabetic (ob/ob) mice. J. Pept. Sci. Off. Publ. Eur. Pept. Soc. 2007, 13, 400-405. [CrossRef] [PubMed]

114. Mathiesen, D.S.; Bagger, J.I.; Bergmann, N.C.; Lund, A.; Christensen, M.B.; Vilsbøll, T.; Knop, F.K. The Effects of Dual GLP-1/GIP Receptor Agonism on Glucagon Secretion-A Review. Int. J. Mol. Sci. 2019, 20, 4092. [CrossRef] [PubMed]

115. Lund, A.; Vilsbøll, T.; Bagger, J.I.; Holst, J.J.; Knop, F.K. The separate and combined impact of the intestinal hormones, GIP, GLP-1, and GLP-2, on glucagon secretion in type 2 diabetes. Am. J. Physiol. Endocrinol. Metab. 2011, 300, E1038-E1046. [CrossRef]

116. Daousi, C.; Wilding, J.P.; Aditya, S.; Durham, B.H.; Cleator, J.; Pinkney, J.H.; Ranganath, L.R. Effects of peripheral administration of synthetic human glucose-dependent insulinotropic peptide (GIP) on energy expenditure and subjective appetite sensations in healthy normal weight subjects and obese patients with type 2 diabetes. Clin. Endocrinol. 2009, 71, 195-201. [CrossRef] [PubMed]

117. Vilsbøll, T.; Krarup, T.; Madsbad, S.; Holst, J.J. Defective amplification of the late phase insulin response to glucose by GIP in obese Type II diabetic patients. Diabetologia 2002, 45, 1111-1119. [CrossRef]

118. Mentis, N.; Vardarli, I.; Köthe, L.D.; Holst, J.J.; Deacon, C.F.; Theodorakis, M.; Meier, J.J.; Nauck, M.A. GIP does not potentiate the antidiabetic effects of GLP-1 in hyperglycemic patients with type 2 diabetes. Diabetes 2011, 60, 1270-1276. [CrossRef]

119. Krarup, T.; Saurbrey, N.; Moody, A.J.; Kühl, C.; Madsbad, S. Effect of porcine gastric inhibitory polypeptide on beta-cell function in type I and type II diabetes mellitus. Metab. Clin. Exp. 1987, 36, 677-682. [CrossRef]

120. Asmar, M.; Arngrim, N.; Simonsen, L.; Asmar, A.; Nordby, P.; Holst, J.J.; Bülow, J. The blunted effect of glucose-dependent insulinotropic polypeptide in subcutaneous abdominal adipose tissue in obese subjects is partly reversed by weight loss. Nutr. Diabetes 2016, 6, e208. [CrossRef]

121. Ceperuelo-Mallafré, V.; Duran, X.; Pachón, G.; Roche, K.; Garrido-Sánchez, L.; Vilarrasa, N.; Tinahones, F.J.; Vicente, V.; Pujol, J.; Vendrell, J.; et al. Disruption of GIP/GIPR axis in human adipose tissue is linked to obesity and insulin resistance. J. Clin. Endocrinol. Metab. 2014, 99, E908-E919. [CrossRef]

122. Schmitt, C.; Portron, A.; Jadidi, S.; Sarkar, N.; DiMarchi, R. Pharmacodynamics, pharmacokinetics and safety of multiple ascending doses of the novel dual glucose-dependent insulinotropic polypeptide/glucagon-like peptide-1 agonist RG7697 in people with type 2 diabetes mellitus. Diabetes Obes. Metab. 2017, 19, 1436-1445. [CrossRef] [PubMed]

123. Portron, A.; Jadidi, S.; Sarkar, N.; DiMarchi, R.; Schmitt, C. Pharmacodynamics, pharmacokinetics, safety and tolerability of the novel dual glucose-dependent insulinotropic polypeptide/glucagon-like peptide-1 agonist RG7697 after single subcutaneous administration in healthy subjects. Diabetes Obes. Metab. 2017, 19, 1446-1453. [CrossRef]

124. Coskun, T.; Sloop, K.W.; Loghin, C.; Alsina-Fernandez, J.; Urva, S.; Bokvist, K.B.; Cui, X.; Briere, D.A.; Cabrera, O.; Roell, W.C.; et al. LY3298176, a novel dual GIP and GLP-1 receptor agonist for the treatment of type 2 diabetes mellitus: From discovery to clinical proof of concept. Mol. Metab. 2018, 18, 3-14. [CrossRef] [PubMed]

125. Rosenstock, J.; Wysham, C.; Frías, J.P.; Kaneko, S.; Lee, C.J.; Fernández Landó, L.; Mao, H.; Cui, X.; Karanikas, C.A.; Thieu, V.T. Efficacy and safety of a novel dual GIP and GLP-1 receptor agonist tirzepatide in patients with type 2 diabetes (SURPASS-1): A double-blind, randomised, phase 3 trial. Lancet 2021, 398, 143-155. [CrossRef]

126. Frías, J.P.; Davies, M.J.; Rosenstock, J.; Pérez Manghi, F.C.; Fernández Landó, L.; Bergman, B.K.; Liu, B.; Cui, X.; Brown, K.; SURPASS-2 Investigators. Tirzepatide versus Semaglutide Once Weekly in Patients with Type 2 Diabetes. N. Engl. J. Med. 2021, 385, 503-515. [CrossRef]

127. Ludvik, B.; Giorgino, F.; Jódar, E.; Frias, J.P.; Fernández Landó, L.; Brown, K.; Bray, R.; Rodríguez, Á. Once-weekly tirzepatide versus once-daily insulin degludec as add-on to metformin with or without SGLT2 inhibitors in patients with type 2 diabetes (SURPASS-3): A randomised, open-label, parallel-group, phase 3 trial. Lancet 2021, 398, 583-598. [CrossRef] 
128. Del Prato, S.; Kahn, S.E.; Pavo, I.; Weerakkody, G.J.; Yang, Z.; Doupis, J.; Aizenberg, D.; Wynne, A.G.; Riesmeyer, J.S.; Heine, R.J.; et al. Tirzepatide versus insulin glargine in type 2 diabetes and increased cardiovascular risk (SURPASS-4): A randomised, open-label, parallel-group, multicentre, phase 3 trial. Lancet 2021, 398, 811-824. [CrossRef]

129. A Study of Tirzepatide (LY3298176) Versus Placebo in Participants with Type 2 Diabetes Inadequately Controlled on Insulin Glargine With or Without Metformin. Available online: https:/ / clinicaltrials.gov / ct2/show / NCT04039503 (accessed on 15 November 2021).

130. Provenzano, M.; Pelle, M.C.; Zaffina, I.; Tassone, B.; Pujia, R.; Ricchio, M.; Serra, R.; Sciacqua, A.; Michael, A.; Andreucci, M.; et al. Sodium-Glucose Co-transporter-2 Inhibitors and Nephroprotection in DiabeticPatients: More Than a Challenge. Front. Med. 2021, 8, 654557. [CrossRef]

131. Garofalo, C.; Borrelli, S.; Liberti, M.E.; Andreucci, M.; Conte, G.; Minutolo, R.; Provenzano, M.; De Nicola, L. SGLT2 Inhibitors: Nephroprotective Efficacy and Side Effects. Medicina 2019, 55, 268. [CrossRef]

132. Coppolino, G.; Leporini, C.; Rivoli, L.; Ursini, F.; Di Paola, E.D.; Cernaro, V.; Arturi, F.; Bolignano, D.; Russo, E.; De Sarro, G.; et al. Exploring the effects of DPP-4 inhibitors on the kidney from the bench to clinical trials. Pharmacol. Res. 2018, 129, 274-294. [CrossRef] [PubMed]

133. Li Vecchi, M.; Fuiano, G.; Francesco, M.; Mancuso, D.; Faga, T.; Sponton, A.; Provenzano, R.; Andreucci, M.; Tozzo, C. Prevalence and severity of anaemia in patients with type 2 diabetic nephropathy and different degrees of chronic renal insufficiency. Nephron. Clin. Pract. 2007, 105, c62-7. [CrossRef]

134. Evers, A.; Haack, T.; Lorenz, M.; Bossart, M.; Elvert, R.; Henkel, B.; Stengelin, S.; Kurz, M.; Glien, M.; Dudda, A.; et al. Design of Novel Exendin-Based Dual Glucagon-like Peptide 1 (GLP-1)/Glucagon Receptor Agonists. J. Med. Chem. 2017, 60, $4293-4303$. [CrossRef] [PubMed]

135. Henderson, S.J.; Konkar, A.; Hornigold, D.C.; Trevaskis, J.L.; Jackson, R.; Fritsch Fredin, M.; Jansson-Löfmark, R.; Naylor, J.; Rossi, A.; Bednarek, M.A.; et al. Robust anti-obesity and metabolic effects of a dual GLP-1/glucagon receptor peptide agonist in rodents and non-human primates. Diabetes Obes. Metab. 2016, 18, 1176-1190. [CrossRef] [PubMed]

136. Usui, R.; Yabe, D.; Seino, Y. Twincretin as a potential therapeutic for the management of type2 diabetes with obesity. J. Diabetes Investig. 2019, 10, 902-905. [CrossRef] 